$$
\text { Pontifícia } \text { Universidade }_{\text {Do Rio de Janeiro }} \text { C }_{\text {atólica }}
$$

Adriana Soares Ito

\title{
Gestão de Estoques de Produtos Intermediários - Estudo de caso de uma Empresa de Petróleo
}

\author{
Dissertação de Mestrado
}

Dissertação apresentada ao Programa de Pós-Graduação em Engenharia de Produção da PUC-Rio como requisito parcial para obtenção do grau de Mestre em Engenharia de Produção.

Orientador: Prof. Antônio Márcio Tavares Thomé

Rio de Janeiro

Junho de 2018 
Adriana Soares Ito

\title{
Gestão de Estoques de Produtos Intermediários - Estudo de caso de uma Empresa de Petróleo.
}

\begin{abstract}
Dissertação apresentada como requisito parcial para obtenção do grau de Mestre (opção profissional) pelo Programa de Pós-Graduação em Engenharia de Produção da PUC-Rio. Aprovada pela Comissão Examinadora abaixo assinada.
\end{abstract}

\author{
Prof. Antônio Márcio Tavares Thomé \\ Presidente e Orientador \\ Departamento de Engenharia Industrial - PUC-Rio
}

Profa. Adriana Leiras

Departamento de Engenharia Industrial - PUC-Rio

Prof. Marcelo Maciel Monteiro Universidade Federal Fluminense - UFF

Prof. Márcio da Silveira Carvalho

Coordenador (a) Setorial do Centro Técnico Científico - PUC-Rio

Rio de Janeiro, 08 de junho de 2018. 
Todos os direitos reservados. É proibida a reprodução total ou parcial do trabalho sem autorização da universidade, da autora e do orientador.

\section{Adriana Soares Ito}

Graduada em Engenharia Química pela Universidade Federal de Minas Gerais (2008). Pós-graduada em Processamento de Petróleo pela Universidade Estadual do Rio de Janeiro, em parceria com a Universidade Petrobras (2009). É funcionária da Petrobras desde 2008, e atua como engenheira de processamento na área de Transferência e Estocagem da Industrial - Sede.

Ficha Catalográfica

Ito, Adriana Soares

Gestão de Estoques de Produtos Intermediários Estudo de caso de uma Empresa de Petróleo / Adriana Soares Ito; orientador: Antônio Márcio Tavares Thomé. $-2018$.

72 f.; $30 \mathrm{~cm}$

Dissertação (mestrado) - Pontifícia Universidade Católica do Rio de Janeiro, Departamento de Engenharia de Produção.

Inclui bibliografia

1. Engenharia Industrial - Teses. 2. Gestão de Estoques. 3. Inventário. 4. Refinaria. 5. Estoque intermediário. 6. Indústria de processo. I. Thomé, Antônio Márcio Tavares. II. Pontifícia Universidade Católica do Rio de Janeiro. Departamento de Engenharia de Produção. III. Título.

CDD: 658.5 


\section{Agradecimentos}

Ao professor Thomé, orientador da dissertação, pela oportunidade, críticas e conhecimentos transmitidos.

À Petrobras pelo patrocínio, incentivo e tempo cedido para o desenvolvimento deste trabalho.

Aos funcionários da Universidade Petrobras, pelo apoio durante todo o período do mestrado.

Aos colegas do curso de mestrado profissional em Logística, pelo compartilhamento das dificuldades e convívio.

À Joana Flor e Lucas Malta, por todas as discussões técnicas, e pelas não técnicas também.

A todos aqueles que de alguma forma me incentivaram para a conclusão deste trabalho. 


\section{Resumo}

Ito, Adriana Soares; Thomé, Antônio Márcio Tavares. Gestão de Estoques de Produtos Intermediários - Estudo de caso em uma empresa de petróleo. Rio de Janeiro, 2018. 72p. Dissertação de Mestrado - Departamento de Engenharia Industrial, Pontifícia Universidade Católica do Rio de Janeiro.

Elevado custo com estoques é um problema enfrentado por muitas empresas brasileiras. Reduzir esse custo mostra-se como uma oportunidade, mas essa redução deve ser acompanhada de uma análise criteriosa, de maneira a não trazer consequências indesejáveis como parada de unidades ou perda de mercado. A presente dissertação teve como objetivos a proposição de um framework de gestão de estoques intermediários baseado em revisão sistemática de literatura seguida de um estudo de caso com entrevistas e observação participante, resultando na análise da gestão de estoques intermediários de uma empresa de óleo e gás. Uma comparação entre as práticas atuais da companhia e o framework foi realizada e recomendações para implantação listadas, através da proposição de um roadmap para implementação do framework. Apontamento de ganho de agilidade e foco na gestão dos estoques intermediários, e redução do inventário são elencados como contribuição desse estudo. As principais recomendações levantadas são referentes à realização da classificação $A B C$ dos estoques, utilização de princípios e ferramentas da filosofia lean, realização de simulações, modelagem e mapeamento de fluxo de valor. Recomendações para estudos futuros incluem técnicas quantitativas de modelagem matemática de estoques e simulações.

\section{Palavras-chave}

Gestão de estoques, inventário, refinaria, estoque intermediário, processo contínuo. 


\section{Abstract}

Ito, Adriana Soares; Thomé, Antônio Márcio Tavares (Advisor). WIP inventory management - Case study in an oil company. Rio de Janeiro, 2018. 72p. Dissertação de Mestrado - Departamento de Engenharia Industrial, Pontifícia Universidade Católica do Rio de Janeiro.

High inventory costs is a problem faced by many Brazilian companies. Reducing these costs can be very beneficial. This reduction needs a careful analysis so as not to bring undesirable consequences, including unit downtime or reduced market share. The goal of this dissertation is to propose an intermediate stock management framework. The proposal is based on a systematic literature review followed by a case study with interviews and participant observation. An analysis of the intermediate stocks management in an oil and gas company is produced. A comparison between the current practices of the company and the proposed framework was carried out. Recommendations and a roadmap on how to implement this framework are offered. Agility in managing intermediate stocks and inventory reduction are pointed as contribution of this study. The main recommendations of this study for the company are related to $A B C$ inventory classification, lean principles and tools, simulation, modelling and value stream mapping. Recommendations for future studies include quantitative techniques for mathematical modeling of inventories and simulations.

\section{Keywords}

Inventory management, inventory, refinery,work in process inventory, continuous process. 


\section{Sumário}

1 Introdução 1

2 Metodologia 5

3 Referencial teórico $\quad 12$

3.1 Frameworks de gestão de estoque 14

3.1.1 A classificação funcional do inventário 14

3.1.2 A classificação ABC como base para modelos de decisão 15

$\begin{array}{ll}\text { 3.1.3 Framework para planejamento de produção e scheduling } & 15\end{array}$

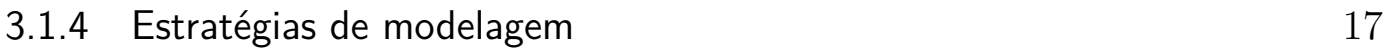

3.1.5 As fases de um estudo sobre inventário 19

3.2 Políticas de estoque 21

3.3 Estoque de produto intermediário e pulmão entre processos 21

3.4 Revisão sistemática sobre gestão de estoques intermediários 23

3.5 Esquemas de Refino 28

4 Estudo de caso $\quad 34$

4.1 Histórico 35

4.2 Entrevistas 38

4.3 Análise dos estoques da empresa 40

4.4 Proposição de framework para gestão de produtos intermediários em uma empresa de petróleo 44

4.5 Comparação do framework proposto e a situação atual 47

5 Conclusões $\quad 53$

6 Apêndice $\quad 55$

6.1 Introdução do estudo de caso 55

6.2 Procedimento de coleta de dados $\quad 55$

6.3 Análise 56

6.4 Validação $\quad 56$

6.5 Apresentação do relatório $\quad 57$

$\begin{array}{ll}\text { Referências bibliográficas } & 58\end{array}$ 


\section{Lista de figuras}

Figura 1.1 Representividade dos custos logísticos em relação ao PIB no Brasil

$\begin{array}{lll}\text { Figura 2.1 } & \text { Processo abdutivo de pesquisa } & 6\end{array}$

$\begin{array}{lll}\text { Figura 2.2 Estágios de desenvolvimento do trabalho } & 7\end{array}$

Figura 3.1 Comparação de resultados entre as melhores empresas e as demais

$\begin{array}{lll}\text { Figura 3.2 } & \text { Estratégias de gestão de inventário } & 13\end{array}$

$\begin{array}{lll}\text { Figura 3.3 Matriz produto-processo } & 18\end{array}$

Figura 3.4 Linha de manufatura com 5 máquinas 22

$\begin{array}{lll}\text { Figura 3.5 Distribuição de artigos selecionados por periódico } & 23\end{array}$

Figura 3.6 Número de artigos por tipo de modelagem 24

$\begin{array}{lll}\text { Figura 3.7 Distribuição de artigos por tema } & 28\end{array}$

$\begin{array}{lll}\text { Figura 3.8 Cadeia de suprimento da indústria de óleo } & 29\end{array}$

$\begin{array}{lll}\text { Figura } 3.9 & \text { Esquema de refino típico } & 31\end{array}$

Figura 4.1 Organograma simplificado da empresa 34

Figura 4.2 Timeline: principais eventos de 2013 a $2018 \quad 38$

Figura 4.3 Distribuição de produtos por tipo 41

Figura 4.4 Distribuição dos estoques por classe secundária 42

Figura 4.5 Distribuição dos estoques por produto 43

Figura 4.6 Framework proposto para a gestão de estoques intermediários

Figura 4.7 Facilidade versus impacto de implementação das recomendações 


\section{Lista de tabelas}

Tabela 1.1 Funcionalidades do estoque 1

$\begin{array}{lll}\text { Tabela 2.1 } & \text { Resultado de busca por artigos } & 8\end{array}$

Tabela 2.2 Número de artigos identificados e selecionados por base de dados 9

Tabela 3.1 Características dos diferentes tipos de processos 16

Tabela 3.2 Sistemas de planejamento da produção e sequenciamento 19

Tabela 3.3 Políticas de estoque 21

Tabela 3.4 Principais características de cada tipo de unidade de processo em uma refinaria 30

Tabela 3.5 Carga e produção das unidades de processo 32

Tabela 3.6 Componentes dos principais produtos de petróleo 33

Tabela 4.1 Identidade do indicador de estoques intermediários $\quad 37$

Tabela 4.2 Recomendações e situação atual evidenciada 48

Tabela 4.3 Recomendações e referências de estudos 50 
Eu sou é eu mesmo. Divêrjo de todo o mundo... Eu quase que nada não sei. Mas desconfio de muita coisa.

Guimarães Rosa, Grande Sertão: Veredas. 


\section{Introdução}

Existem várias razões pelas quais os empresas decidem fazer e manter estoques. Quatro grandes funções podem ser elencadas: especialização geográfica, desacoplamento, equilíbrio entre oferta e demanda e proteção contra incertezas (Bowersox et al., 2014) . Na tabela 1.1 são detalhadas essas funcionalidades.

Tabela 1.1: Funcionalidades do estoque

\begin{tabular}{ll}
$\begin{array}{l}\text { Especialização geográ- } \\
\text { fica }\end{array}$ & $\begin{array}{l}\text { Permite o posicionamento geográfico em di- } \\
\text { versas unidades de produção e distribuição } \\
\text { de uma empresa. Estoques mantidos em di- } \\
\text { ferentes locais e etapas de processo de criação } \\
\text { de valor permitem a especialização. }\end{array}$ \\
\hline Desacoplamento & $\begin{array}{l}\text { Permite economia de escala dentro de uma } \\
\text { única instalação e consente que cada processo } \\
\text { opere com eficiência máxima ao invés de todo } \\
\text { o processo ser limitado pela etapa mais lenta. }\end{array}$ \\
\hline Equilíbrio entre oferta e & $\begin{array}{l}\text { Acomoda o tempo decorrido entre a disponi- } \\
\text { demanda }\end{array}$ \\
& $\begin{array}{l}\text { bilidade de estoque (fabricação, crescimento } \\
\text { ou extração) e o consumo. }\end{array}$ \\
\hline Proteção contra incerte- & $\begin{array}{l}\text { Acomoda as incertezas relacionadas à de- } \\
\text { manda em excesso ou atrasos previstos ou }\end{array}$ \\
& $\begin{array}{l}\text { inesperados no recebimento e no processa- } \\
\text { mento de pedidos. Normalmente é chamado } \\
\text { de estoque de segurança. }\end{array}$
\end{tabular}

Fonte: (Bowersox et al., 2014)

Uma outra funcionalidade pode ser apontada, a do estoque especulativo (Jaffe \& Soligo, 2002). Esse tipo de estoque é feito quando as empresas tem a expectativa que os preços futuros dos produtos sejam substancialmente diferentes dos atuais.

A separação funcional do inventário é importante para chamar atenção do seu propósito organizacional, especialmente no que diz respeito ao controle e gestão (Silver et al., 2016). Outra divisão possível, de grande importância 
principalmente para as indústrias de manufatura é a de estoque de matéria prima, estoque intermediário e estoque de produto acabado.

O estoque de matéria prima é mantido para a produção e sua falta pode ser muito onerosa já que pode levar à parada de toda uma linha de processo. A matéria prima também é mais barata que o produto acabado, então é facilmente argumentável a necessidade do seu estoque (Waller \& Esper, 2014).

O estoque de produto acabado é aquele que está em sua forma final logo após a produção. Devido ao seu maior valor agregado, é mais caro mantêlo que o estoque intermediário, que por sua vez é mais caro que o estoque de matéria prima. Adicionalmente, o estoque de produto acabado pode se deteriorar, se tornar obsoleto, ser roubado. Obviamente isso pode acontecer com os estoques de matéria prima e com o estoque intermediário, mas é muito mais provável que aconteça com o produto final (Waller \& Esper, 2014).

O estoque de produto intermediário é o inventário que ao longo do processo é transformado em produto final. Esse tipo de estoque é encontrado na indústria em vários estágios: ele pode estar presente entre unidades de processo em uma linha ou aguardando montagem ou mistura para transformação em produto final.

Um estudo publicado pela AMR Research mostrou que os custos com estoques em 2000 excediam U $\$ 60$ bilhões nos EUA e U\$120 bilhões no mundo (Crandall \& Crandall, 2003). De acordo com levantamentos realizados pelo Instituto Ilos (M. Lima, 2014), os custos logísticos do Brasil equivaleram a 11,5\% do PIB em 2012, enquanto os Estados Unidos gastaram o referente a $8,3 \%$ do PIB no mesmo ano.

Na figura 1.1, o custo total com estoque no Brasil no período entre 2004 e 2012 ficou por volta de 3,4\% (média do período) do PIB do país.

Mas quais são os custos relacionados aos estoques, que levam a números tão expressivos? Os principais tipos de custos relacionados ao estoque são os custo de oportunidade, os custos de armazenamento e o custo da falta (Waller \& Esper, 2014).

O custo de oportunidade é o primeiro elemento normalmente apontado em se tratando de estoques. De maneira simplificada, ele representa o que poderia ser feito com o valor monetário que se encontra investido no estoque. Como esse custo é difícil de julgar, em geral as empresas consideram o custo do capital para representar o custo da manutenção dos estoques.

O custo de armazenamento leva em conta custos como o operacional, 


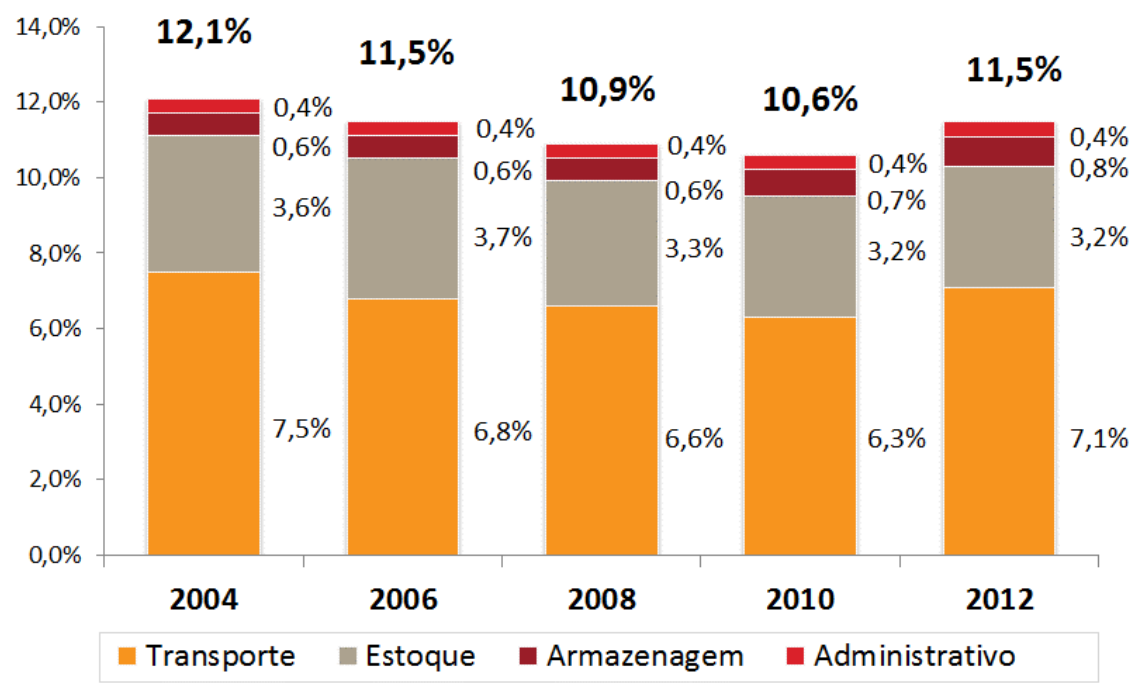

Figura 1.1: Representividade dos custos logísticos em relação ao PIB no Brasil Fonte: Instituto Ilos (M. Lima, 2014)

de equipamentos, de funcionários e de aluguel das instalações. Deve se ter particular atenção quanto à variação do mesmo em função do tamanho do inventário. Nesse quesito, entram também os custos relacionados a impostos e os custos de seguro dos produtos. Devem ser considerados ainda custos de encolhimento que são associados a roubo, perda e deterioração. Frutas são um bom exemplo no qual há impacto de redução, devido à deterioração. Produtos que se tornam obsoletos (como no caso de expiração de prazo de validade), podem também levar a custos de obsolescência.

Se por um lado é caro ter o inventário, por outro também é caro não o ter. Este é o custo da falta do estoque. que no caso de um produtor incluem gastos relativos a mudanças nos equipamentos para produção de ordens de emergência, ao replanejamento, à divisão de lotes. Existe ainda custos que não são facilmente calculados como o do não atendimento à demanda do cliente que pode, inclusive, levar à perda do mesmo (Silver et al., 2016). No contexto de uma linha de produção, o custo da falta também está diretamente ligado à ociosidade das unidades de processo, e aos custos de parada e partida das plantas.

Dessa maneira, existe um trade off considerando os custos acima elencados para a definição do nível de estoque em que a empresa irá trabalhar. Em uma perspectiva balanceada, o ótimo é alcançado através da manutenção do nível de inventário adequado para amortecer os fluxos de suprimento, produção e comercialização, ao mesmo tempo em que esse nível é minimizado, de 
maneira a melhorar o desempenho financeiro da empresa.

O presente trabalho é um estudo de caso sobre a gestão de estoques intermediários na indústria de petróleo. Os estoques intermediários são encontrados nas refinarias, ao longo do processamento do petróleo e podem ser utilizados como carga de unidades e/ou como componentes para a obtenção dos produtos finais.

Nesse estudo pretende-se responder à pergunta de pesquisa "Quais as práticas de gestão de estoques intermediários são empregadas na indústria de processo em geral e quais poderiam ser aplicadas ao estudo de caso de maneira a melhorar a gestão?". Dessa maneira, após a apresentação dos conceitos gerais referentes à gestão de estoques, são analisados os resultados de uma revisão sistemática da literatura para avaliação das principais abordagens atualmente utilizadas na gestão de estoques intermediários na indústria de processo.

Na sequência, são mapeadas as práticas empregadas na companhia estudada através da análise de evidências dos tipos registros, documentos, observação participante, entrevistas e aquisição de dados. Os dados são validados através de triangulação e análise por um verificador não tendencioso.

Com base na revisão sistemática da literatura e análise do estudo de caso, é proposto um framework de melhoria da gestão dos estoques intermediários na empresa. Esse framework é comparado à prática atual, e os impactos e facilidade de sua implementação são avaliados. 


\section{Metodologia}

O presente estudo é considerado descritivo e de melhoria, já que tem como objetivo descrever as variáveis de uma determinada situação, entender as características de uma organização que segue uma determinada prática em sua rotina e propor uma nova configuração, baseada no referencial teórico. Adicionalmente, a pesquisa é considerada qualitativa uma vez que relaciona conceitos, caracterizada pelo uso de métodos que tentam investigar os traços inerentes aos fatos e fenômenos, sem o levantamento quantitativo de dados.

Essa dissertação enquadra-se também na abordagem abdutiva. Ao invés de se concentrar apenas em generalizações e/ou suas manifestações específicas, a abordagem abdutiva preocupa-se com particularidades de situações que se desviam da estrutura geral. Assim ajuda a determinar quais aspectos de uma situação são generalizáveis e quais outros pertencem apenas à própria situação específica decorrente, por exemplo, de fatores situacionais (Kovács \& Spens, 2005).

Na abordagem abdutiva, o pesquisador está constantemente reavaliando e desenvolvendo o referencial teórico, os dados e a estrutura, à medida que a pesquisa avança. Esse processo é chamado de "combinação sistemática" (Dubois \& Gadde, 2002). Ao passo que os dados vão sendo coletados e novas ideias sobre o caso são criadas, pode haver redirecionamento na estrutura do trabalho, ou no referencial teórico, permitindo o desenvolvimento de novas perspectivas. Assim, a teoria e os dados empíricos levam a melhores resultados quando combinados. A figura 2.1 apresenta esse processo. Durante o desenvolvimento desse estudo, o referencial teórico foi primeiramente elaborado e o estudo de caso iniciado. Nessa fase, houve necessidade de realinhamento do referencial, já que durante a coleta de evidências ficou claro uma necessidade de aprofundamento teórico na gestão de estoques intermediários. Além disso, houve necessidade ao longo do projeto de redefinição dos tipos de evidências a serem coletadas. Esses fatos corroboram a categorização do projeto no método abdutivo de pesquisa.

O projeto de pesquisa deve expor os estágios que conduziram o estudo, como apresentado na figura 2.2. O detalhamento das fases é apresentado na 


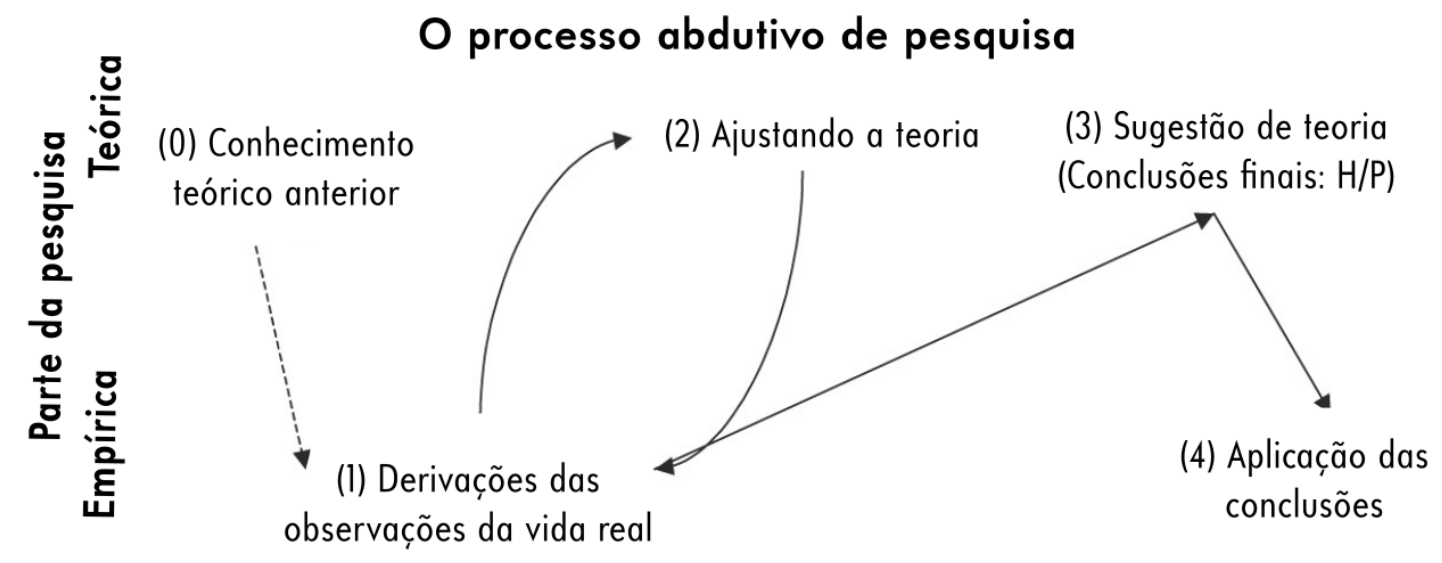

Figura 2.1: Processo abdutivo de pesquisa

Fonte: (Kovács \& Spens, 2005)

sequência.

$\mathrm{Na}$ fase de definição do objetivo e escopo do trabalho, o problema a ser estudado, a pergunta de pesquisa e os objetivos foram definidos. Foram apresentadas também limitações conhecidas do trabalho, ou seja, o que não é coberto no escopo do estudo. Essa análise está detalhada no Capítulo 1, de introdução.

Para a verificação do conhecimento existente, foram usadas duas abordagens. A primeira foi a de construção do referencial teórico. Na sequência, por ter sido encontrado uma necessidade de aprofundamento no tema de gestão de estoques intermediários, foi realizada uma revisão bibliográfica sistemática detalhada a seguir.

A revisão sistemática tem como objetivo reportar o estado atual de um determinado campo de conhecimento. Ela é diferente de uma revisão não sistemática já que segue um plano estruturado, com uma sequência definida de estágios (C. Oliveira et al., 2017). Pode-se dizer que revisão sistemática é um importante esforço de pesquisa em si. Oito passos são propostos para a realização de uma revisão bibliográfica sistemática (Thomé et al., 2016), listados a seguir:

1. Planejamento e formulação do problema;

2. Busca na literatura; 


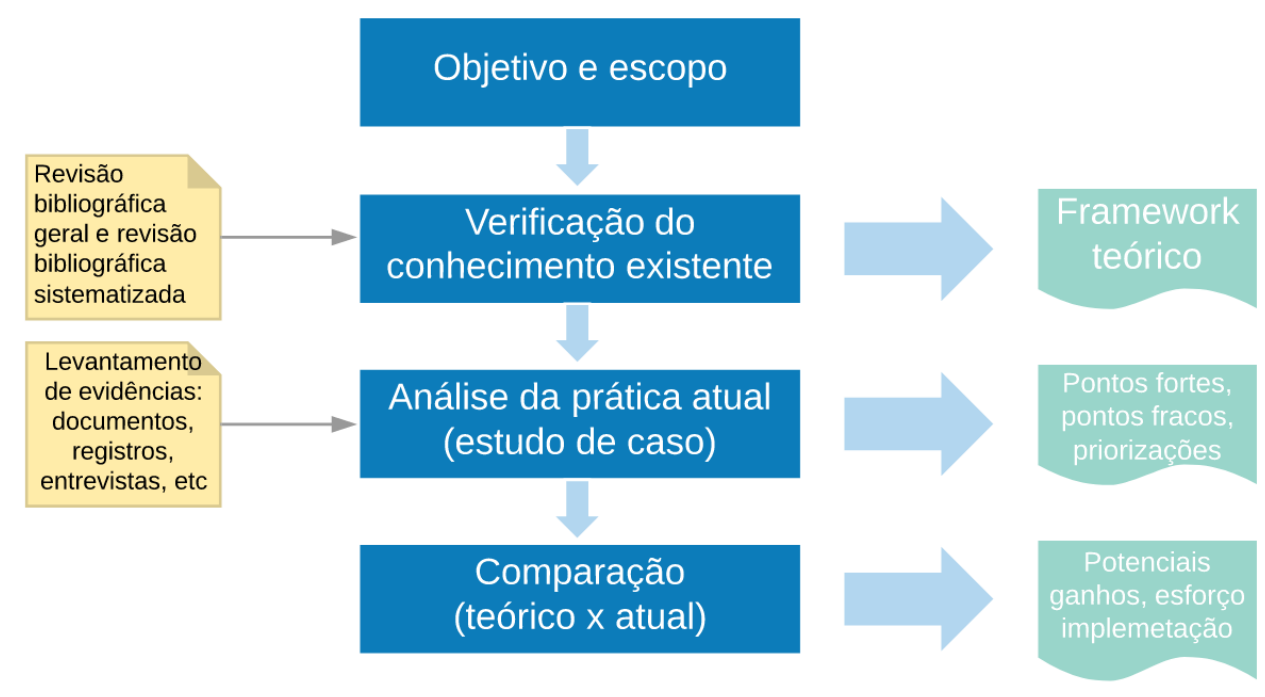

Figura 2.2: Estágios de desenvolvimento do trabalho Fonte: Elaboração própria

\author{
3. Coleta de dados; \\ 4. Avaliação da qualidade; \\ 5. Análise dos dados e síntese; \\ 6. Interpretação dos dados; \\ 7. Apresentação dos resultados e \\ 8. Atualização da revisão.
}

No primeiro estágio, após a elaboração do referencial teórico, foi identificada a necessidade de aprofundamento em relação a questões que ainda não estavam respondidas relativas à gestão de estoques intermediários. Como norte do trabalho, foi utilizada pergunta de pesquisa: "Quais as principais práticas de gestão de inventários intermediários são empregadas atualmente na indústria de processo?". Foram definidas mais que duas bases de dados para a pesquisa, de maneira a garantir uma maior diversidade de artigos. São elas: Science Direct, Springer, Scopus e Emerald. A tabela 2.1 apresenta o resultado da busca de artigos por base.

Inicialmente, utilizou-se as palavras-chaves e expressões lógicas "inventory management" and "work in process" para a busca. Na sequência, a seguinte combinação de palavras foi usada: "inventory management" and 
Tabela 2.1: Resultado de busca por artigos

\begin{tabular}{llllll} 
Palavras-chaves & Scopus & $\begin{array}{l}\text { Science } \\
\text { Direct }\end{array}$ & $\begin{array}{l}\text { Springer } \\
\text { Link }\end{array}$ & Emerald & Total \\
\hline $\begin{array}{l}\text { "Inventory manage- } 52 \\
\text { ment" and "work in } \\
\text { process" }\end{array}$ & 608 & 704 & 0 & 1364 \\
\hline $\begin{array}{l}\text { "Inventory manage- } \\
\text { ment" and "work in } \\
\text { process" and "process } \\
\text { industry" }\end{array}$ & & & & \\
\hline \\
Critério de exclusão
\end{tabular}

Fonte: Elaboração própria

"process industry" and "work in process". A escolha de inclusão da expressão "indústria de processo" foi feita devido às especificidades desse tipo de indústria: produção contínua ou em batelada a partir de mistura, separação ou reação química de materiais líquidos, borras ou gasosos (não discretizáveis) e conteinerização dos produtos (Dennis \& Meredith, 2000).

Foram considerados apenas artigos e publicações em conferências em data superior a 2000 para enfatizar estudos mais recentes e cobrir as práticas de gestão mais atuais. Vale ressaltar que os artigos com data inferior a 2000 foram posteriormente analisados, com leitura de resumo e conclusão, para avaliação de possibilidade de inclusão no escopo do projeto, porém não houve necessidade de atualização. Foram pesquisados apenas artigos na língua inglesa.

Dos 40 artigos selecionados, não foi observada duplicação entre as bases (mesmo artigo em mais de uma base). A tabela 2.2 mostra o número de artigos encontrados por base pesquisada e o número de artigos selecionados após leitura dos resumos. O critério para inclusão/exclusão de artigos foi a adequação de conteúdo ao tema proposto nessa dissertação. Para isso foi realizada leitura do resumo, introdução e conclusão de cada um dos artigos e observados indícios de aplicação de alguma prática ou ferramenta para a gestão de estoques intermediários. Ao final da análise, foram escolhidos 15 artigos para a leitura completa. 
Tabela 2.2: Número de artigos identificados e selecionados por base de dados

\begin{tabular}{lcc} 
Base & Artigos identificados & Artigos selecionados \\
\hline Science Direct & 25 & 9 \\
Springer & 14 & 5 \\
Scopus & 1 & 1 \\
Emerald & 0 & 0 \\
\hline
\end{tabular}

Fonte: Elaboração própria

Na etapa de coleta de dados e avaliação da qualidade, foram exportados os dados referentes aos artigos selecionados através de ferramentas disponíveis nas bases de pesquisa. As etapas de análise e interpretação de dados são os quinto e sexto passos, respectivamente (Thomé et al., 2016). Ambos estágios foram realizados através da avaliação do conteúdo, com uma etapa correspondente à síntese. A apresentação dos resultados (sétimo passo) é realizada no Capítulo 3, de Referencial Teórico. A última fase, atualização da revisão, não fez parte do escopo desse estudo.

De posse do referencial teórico e da revisão sistemática, foi proposto um framework teórico para a gestão de estoques intermediários, apresentado no Capítulo 4.

Esse estudo é considerado um estudo de caso, já que é uma investigação empírica de um fenômeno contemporâneo dentro do contexto da vida real. Estudo de caso é uma estratégia preferível quando existe o desejo de se responder às perguntas "Como?" e "Por quê?" e o observador possui baixo controle sobre os eventos (Yin, 2009).

Como uma estratégia de pesquisa, o estudo de caso é usado em muitas situações de maneira a contribuir para o conhecimento de um determinado fenômeno no nível individual, do grupo, ou da organização. O método permite ao investigador reter as características holísticas e significantes dos eventos da vida real - como de processos organizacionais e gerenciais. Esse é o caso do presente trabalho.

O projeto em questão trata-se de um caso singular, já que apenas uma empresa de petróleo foi foco da pesquisa. Adicionalmente, um único processo de gestão de estoques foi avaliado. O objeto de estudo foi o processo de gestão de estoques intermediários em uma empresa de óleo e gás, que corresponde à unidade de análise. A unidade de análise embutida identificada foi a estrutura organizacional na qual o processo transcorre. Essa definição foi realizada de acordo com a proposição de (Yin, 2009) referente a estudos de caso. 
Foram considerados os passos propostos por (Yin, 2009) no estudo de caso. São eles: identificação do estudo de caso, preparação para coleta de evidências, coleta das evidências, análise das evidências e apresentação. Para a identificação, preparação e coleta, foi estabelecido um protocolo, apresentado no Apêndice.

Seis principais tipos de evidências podem ser usadas no estudo de caso (Yin, 2009), (Gillham, 2000). São elas:

1. Documentos: cartas, políticas internas, regulamentos, diretrizes;

2. Registros: evidências que voltam no tempo e que podem produzir uma linha longitudinal até o presente, muitas vezes arquivadas em pastas ou sistemas em computadores;

3. Entrevistas: existem várias maneiras através das quais as pessoas podem oferecer informações, como discussão espontânea ou questionários, por exemplo;

4. Observação direta: o pesquisador não interfere de nenhuma maneira, ele só escuta e observa;

5. Observação participante: muito comum no estudo de caso, o pesquisador está no "cenário" e de alguma maneira se encontra ativo;

6. Artefatos físicos: evidências produzidas através de amostras.

Os seguintes tipos de evidência foram coletados: documentos; registros; entrevistas e observação participante. Para o levantamento documental, foram analisados documentos disponíveis em pasta eletrônica do setor, como apresentações e relatórios. Para o levantamento de registros, foram analisadas atas de reunião registradas e documentos internos e externos oficiais. A observação participante foi realizada através da participação em reuniões específicas sobre o assunto na empresa. Para a realização das entrevistas, foram definidas cinco perguntas que foram feitas para os pontos focais de gestão de estoques nas unidades operacionais e sede. Na primeira pergunta, foi solicitado que os entrevistados apontassem em suas visões qual a finalidade dos estoques intermediários. Na sequência, foi questionado se a definição das metas ocorre com participação multi-disciplinar. Foi também indagado se fatores monetários, confiabilidade de processos e parada programada de unidades são considerados na definição das metas (terceira, quarta e quinta perguntas). 
A partir das evidências do tipo registro, foi construída uma linha do tempo, para entendimento e interpretação do processo ao longo do período estudado. A análise documental foi utilizada para verificação dos conceitos, ideias e diretrizes implantados na empresa. As entrevistas, assim como a observação participante, subsidiaram a avaliação do entendimento e engajamento da força de trabalho na gestão.

De maneira a garantir a validade e confiabilidade do estudo foram verificadas múltiplas fontes de evidências, com estabelecimento da cadeia de evidências. Os dados levantados nos documentos e registros foram triangulados com as respostas recebidas das entrevistas. Adicionalmente, o rascunho do relatório foi apresentado para revisão por um verificador não tendencioso que trabalha na unidade de análise investigada e conhece bem o processo estudado. Os estudos externos encontrados ao longo do trabalho foram via de regra concordantes com os resultados obtidos. 


\section{3}

\section{Referencial teórico}

Uma pesquisa do tipo survey com mais de 160 empresas sobre gestão de estoques aponta que apenas $11 \%$ das empresas acreditam que suas tecnologias de gestão de inventário suportam seus processos de vendas e planejamento de operações, também conhecido como S\&OP, enquanto que $57 \%$ delas desejam incorporar a gestão de inventários em seu processo de S\&OP (Aberdeen, 2006).

Os resultados alcançados pelas empresas com melhores indicadores quanto à gestão do inventário são apresentadas na figura 3.1. A comparação com as demais empresas é realizada. Os seguintes resultados são notáveis: redução dos custos de manutenção de estoque; redução dos custos com inventário obsoleto; redução do lead time para os clientes e aumento do giro do estoque dos produtos acabados.

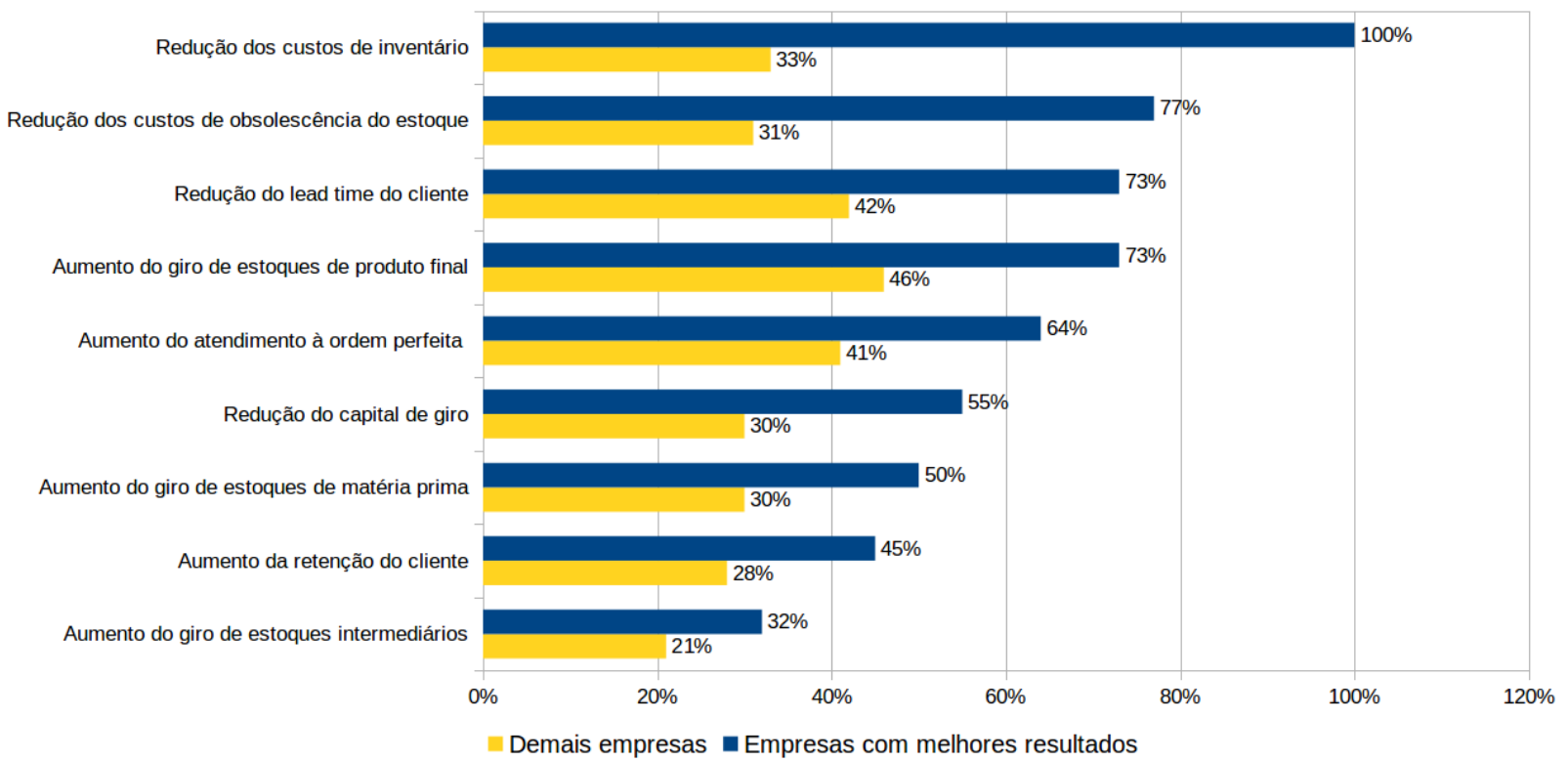

Figura 3.1: Comparação de resultados entre as melhores empresas e as demais Fonte: (Aberdeen, 2006)

As características identificadas no estudo que diferenciam as empresas 
com os melhores resultados são a otimização escalonada do inventário, a utilização de sistema com alta visibilidade da cadeia e a utilização de ferramenta eficaz para previsão de demanda. Um maior percentual das empresas com melhores resultados realizam otimização de estoques multi-escalão (36\%), possuem um sistema de visibilidade da cadeia de suprimentos (57\%) e utilizam um sistema de previsão que suporta a previsão ao nível do cliente (52\%). Para as demais empresas, os mesmos números são 17\%, 27\% e 27\%, respectivamente (Aberdeen, 2006).

As principais ações para a melhoria da gestão do inventário identificadas são, nessa ordem: otimizar quanto e onde o inventário está alocado na cadeia, melhorar a acurácia das previsões, aumentar a visibilidade da cadeia de suprimento, melhorar a capacidade de atender o prazo requerido pelo cliente, responsabilizar os fornecedores pelo inventário. As estratégias utilizadas pelas empresas com melhor desempenho em relação à gestão de estoques é comparada com as utilizadas pelas demais empresas na figura 3.2. Enquanto grande parte das melhores empresas focam na classificação ABC do inventário e a na otimização multi-elo, as demais empresas continuam utilizando regras gerais para controle dos estoques.

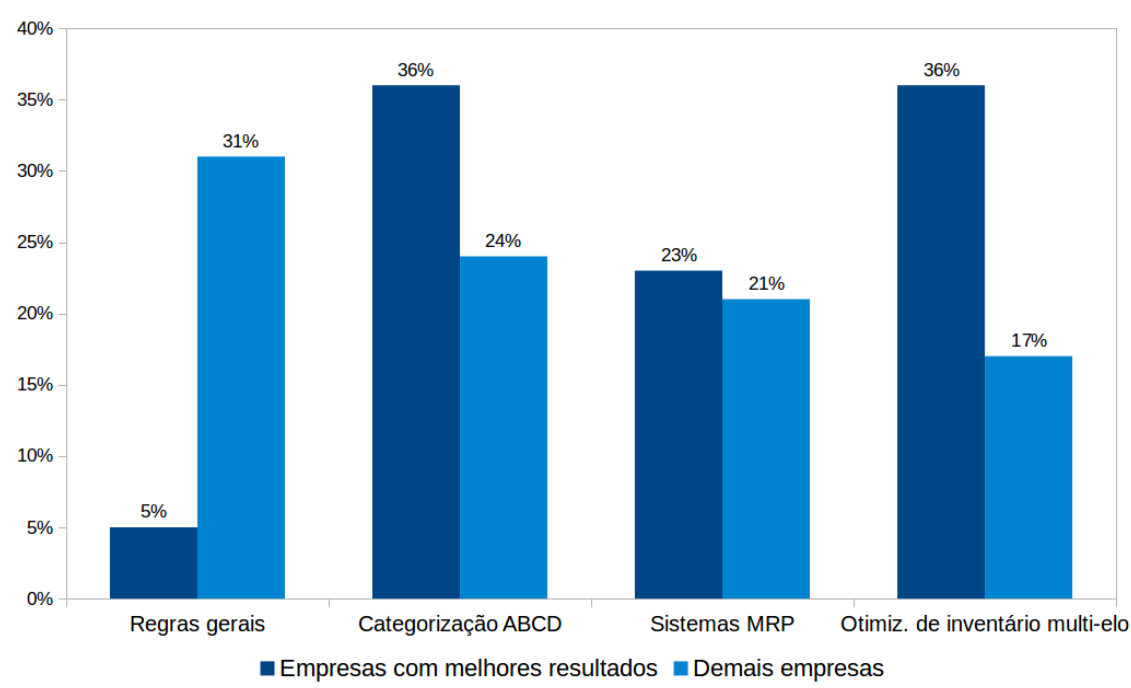

Figura 3.2: Estratégias de gestão de inventário Fonte: (Aberdeen, 2006)

O estudo demonstra ainda que as empresas que estão acima da média em relação ao desempenho quanto ao inventário atualizam a estratégia e políticas de inventário muito mais frequentemente (várias vezes ao ano) que as demais empresas (anual ou plurianual). 


\section{1}

\section{Frameworks de gestão de estoque}

A complexidade do gerenciamento de inventário e do planejamento de produção é alta e por isso são apresentados alguns frameworks para direcionamento de como se lidar com essa complexidade (Silver et al., 2016). São eles: a classificação funcional do inventário, a classificação $\mathrm{ABC}$, o framework para planejamento de produção e scheduling, estratégias de modelagem e a separação das fases de um estudo de inventário.

\subsection{1}

\section{A classificação funcional do inventário}

Seis categorias de estoques agregados para controle são recomendadas (Silver et al., 2016): estoque de ciclo, estoque de congestionamento (congestion stock), estoque de segurança (ou buffer), estoque de antecipação, estoque em linha e estoque de desacoplamento.

Os estoques de ciclos resultam da produção e pedidos em bateladas, ao invés de uma unidade por unidade de tempo. A quantidade de estoque disponível resultante da produção e entrega em lotes é chamada de estoque de ciclo. Algumas razões para a produção em bateladas são: economia de escala, descontos por quantidade no preço de compra ou no custo do frete e restrições tecnológicas como o tamanho fixo de um tanque em um processo químico.

Os estoques de congestionamento são aqueles que ocorrem devido a itens competindo por capacidade limitada. Quando múltiplos itens compartilham o mesmo equipamento de produção, os estoques desses itens podem se acumular à medida que esperam que o equipamento esteja disponível para processamento.

Estoque de segurança é a quantidade de estoque mantida em mãos para absorver a incerteza da demanda e da oferta no curto prazo. Estoques de segurança não são necessários quando se há certeza sobre as variáveis do processo, como a demanda e o lead time.

Estoque de antecipação é aquele que é acumulado antes de algum pico esperado nas vendas. Pode ocorrer devido à sazonalidade do suprimento ou da demanda.

Estoques em linha ou estoques intermediários incluem produtos em trânsito (em dutos ou em caminhões, por exemplo), ao longo do sistema de distribuição e estoques entre os estágios em uma fábrica. 
O estoque de desacoplamento é usado de maneira a possibilitar a tomada de decisão nos diferentes elos de uma cadeia. Por exemplo, ele permite que cada filial possa tomar suas decisões sobre o estoque sem que haja um impacto imediato sobre o armazém central de distribuição, ou sobre a fábrica.

\subsection{2}

\section{A classificação $\mathrm{ABC}$ como base para modelos de decisão}

Decisões de gestão relativas a inventário devem ser realizadas, em última instância, no nível do item individual ou por produto (Silver et al., 2016). A unidade específica a ser controlada é chama de unidade de manutenção de estoque (SKU - stock-keeping unit). No caso de uma empresa de petróleo, por exemplo, cada tipo diferente de petróleo é um tipo de SKU. Tipicamente, $20 \%$ do SKU são responsáveis por $80 \%$ dos custos associados. Isso sugere que todo o inventário de uma empresa não pode ser controlado da mesma maneira.

Através da construção de uma tabela e uma curva de distribuição de valor, na qual o valor de cada tipo de SKU e seu volume são considerados, pode-se identificar quais os itens mais importantes no estoque desagregado. É possível assim separar os itens que devem ter alta prioridade de alocação do tempo de gerenciamento e de recursos financeiros em qualquer sistema de decisão que seja desenhado. Normalmente são usadas três categorias: A (muito importante), B (intermediário) e C (menos importante). Obviamente, os itens A devem ter atenção mais personalizada da gestão, os itens B são secundários e os itens $\mathrm{C}$ devem possuir sistemas de controle o mais simples possível. A definição da política de estoque deve ser realizada de acordo com o tipo do item.

\subsection{3}

\section{Framework para planejamento de produção e scheduling}

Quatro grandes classes de processos podem ser diferenciadas de acordo com (Hayes \& Wheelwright, 1979) e (Silver et al., 2016): job shop - por encomenda, fluxo em batelada, linha de montagem e processo contínuo. A tabela 3.1 mostra os principais contrastes entre os diferentes tipos de processos.

Devido à natureza padronizada dos produtos nas indústrias de processo, há uma tendência da produção para estoque. As linhas de montagem são direcionadas para fazer para estocar (make-to-stock) e montar sob pedido (assemble-to-order), enquanto os processos do tipo job shop normalmente se direcionam por fazer sob pedido (make-to-order). Processo de fluxos em 


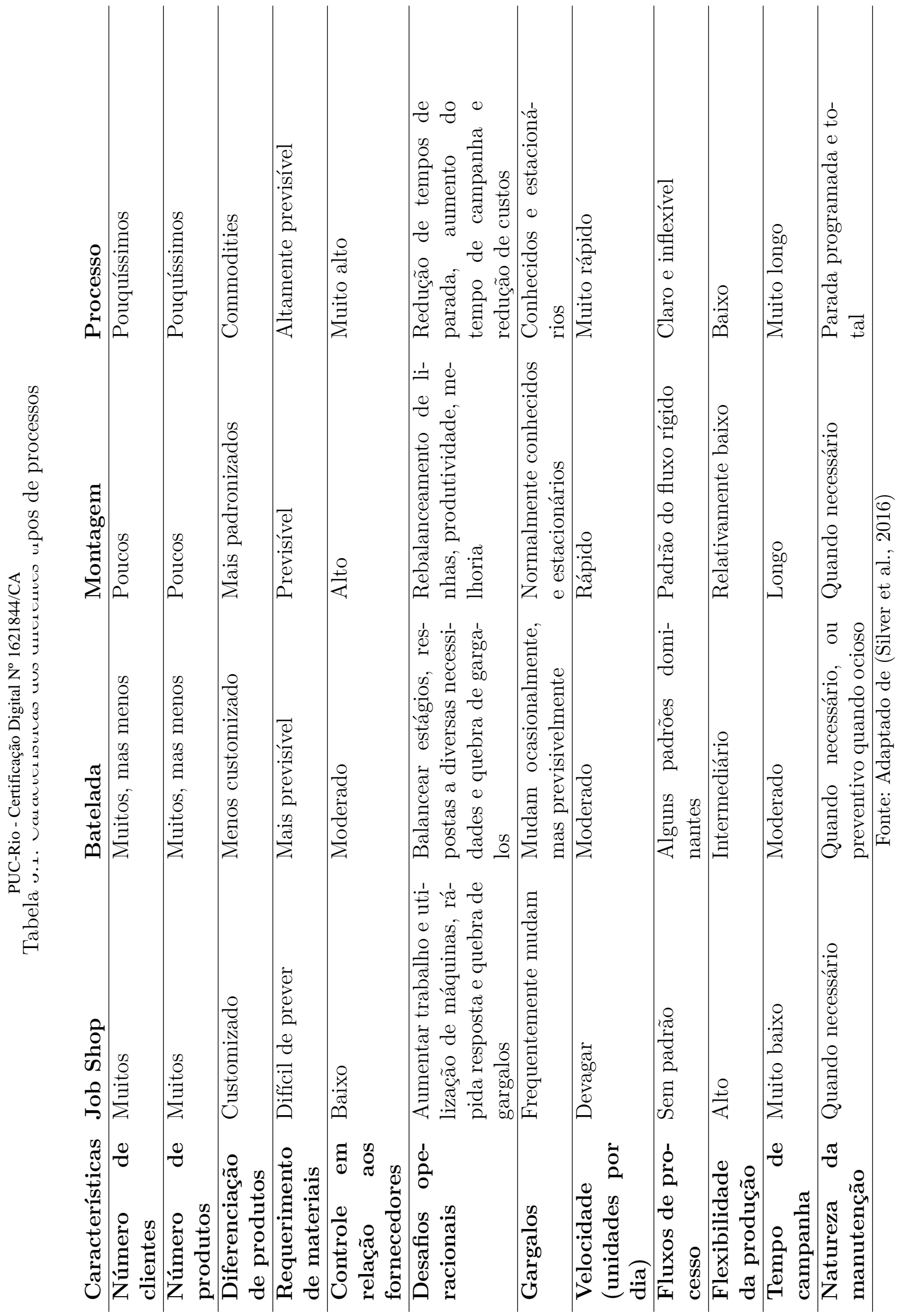


batelada podem ser do tipo fazer para estocar (make-to-stock) ou fazer sob pedido (make-to-order), dependendo dos tipos de produto e clientes.

As linhas de produção em indústrias de processo tendem a ser dedicadas a um número relativamente pequeno de produtos com relativamente pouca flexibilidade para alterar a taxa ou a natureza da saída. Nesse ambiente, a capacidade é bem definida pela operação limitante (gargalo). À esquerda da tabela 3.1, tende a haver mais flexibilidade na taxa e na saída de produtos. Além disso, tanto o gargalo quanto a capacidade associada tendem a mudar com a natureza da produção (que produtos estão sendo produzidos e em que quantidades).

Pelo alto grau de investimento em equipamentos e pela flexibilidade relativamente baixa na taxa de produção, indústrias de processo tendem a funcionar em plena capacidade (ou seja, 3 turnos por dia, 7 dias por semana). O fluxo do processo exige equipamentos altamente confiáveis que, por sua vez, requerem manutenção preventiva. Essa manutenção é geralmente realizada durante uma parada geral de longa duração. Job shops e indústrias de fluxo em batelada tendem a usar equipamentos menos caros. A manutenção pode ser feita "sempre que necessário". As linhas de montagem são mais flexíveis do que os processos contínuos, mas menos que job shops e linhas de fluxo em batelada. Muitas vezes, o equipamento é muito barato - simplesmente ferramentas manuais; mas também pode ser utilizada a montagem automatizada, que requer alto investimento. Assim, políticas de manutenção tendem a se basear no custo do equipamento.

Uma matriz de produto-processo para os diferentes tipos de padrão encontrados na indústria é apresentada na figura 3.3 (Hayes \& Wheelwright, 1979), (Silver et al., 2016). O processo fabril, encontra-se no topo, à esquerda, e as indústrias de processo estão na direção da direita, abaixo. O sistema indicado para o planejamento da produção e para o sequenciamento, encontrase na linha diagonal. A tabela 3.2 brevemente descreve o foco primário de cada um dos sistemas.

\subsection{4}

\section{Estratégias de modelagem}

Existem três tipos de estratégias envolvendo modelagens (Silver et al., 2016): modelagem detalhada e seleção analítica dos valores de um número limitado de variáveis de decisão; modelagem de escopo mais amplo, com menor tentativa de otimização, e minimização de inventários com muito pouca 


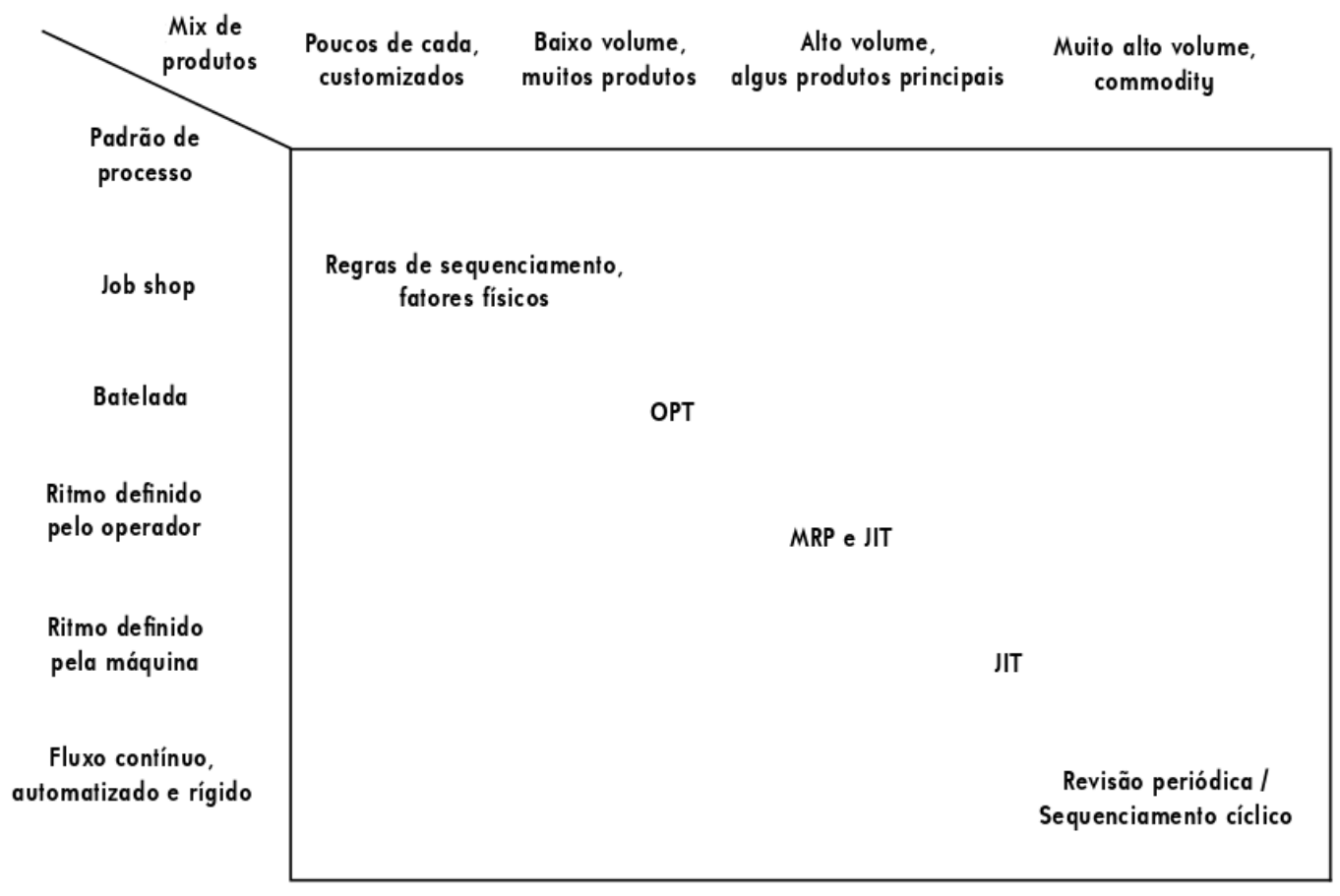

Figura 3.3: Matriz produto-processo

Fonte: (Hayes \& Wheelwright, 1979), (Silver et al., 2016)

utilização de modelos matemáticos.

Na modelagem detalhada, a estratégia é o desenvolvimento de modelos matemáticos que permitem a seleção de valores de um determinado número de variáveis, permitindo a otimização de alguma medida eficaz. O exemplo clássico é a quantidade econômica de pedido que minimiza o custo total de pedido e de manutenção de estoques. Em geral, um modelo matemático permite uma solução dedutiva, interativa, ou uma solução de tentativa e erro.

Na modelagem de escopo mais amplo e com menos otimização, a estratégia é tentar desenvolver um modelo realístico para uma situação particular. No entanto, o realismo adicional normalmente impede uma otimização clara e definida. Na verdade, pode inclusive não existir uma função objetivo matemática definida. Procura-se por uma solução possível, com a esperança de um desempenho razoável. Essa é a filosofia por trás do MRP (material requirements planning).

No caso da minimização do inventário com pouca modelagem, procurase minimizar estoques sem a ajuda de modelos matemáticos. As filosofias JIT (just in time) e OPT (optimized production technology - tecnologia de produção 
Tabela 3.2: Sistemas de planejamento da produção e sequenciamento

\begin{tabular}{|c|c|c|}
\hline Sistema & $\begin{array}{l}\text { Natureza relevante da } \\
\text { indústria }\end{array}$ & $\begin{array}{l}\text { Foco primário do sis- } \\
\text { tema }\end{array}$ \\
\hline $\begin{array}{l}\text { Regras de sequen- } \\
\text { ciamento e fatores } \\
\text { físicos }\end{array}$ & $\begin{array}{l}\text { Baixo volume de fabrica- } \\
\text { ção }\end{array}$ & $\begin{array}{l}\text { Flexibilidade para aten- } \\
\text { der diferentes ordens, } \\
\text { atendimento aos prazos, } \\
\text { aumento de produção e } \\
\text { previsão dos lead times }\end{array}$ \\
\hline OPT & $\begin{array}{l}\text { Batelada, baixo volume } \\
\text { de montagem }\end{array}$ & $\begin{array}{l}\text { Gestão de restriçõos (en- } \\
\text { gargalamentos) }\end{array}$ \\
\hline $\begin{array}{l}\text { Planejamento de } \\
\text { recursos materiais } \\
\text { (MRP - Material } \\
\text { resources planning) }\end{array}$ & $\begin{array}{l}\text { Volume médio de monta- } \\
\text { gem }\end{array}$ & $\begin{array}{l}\text { Coordenação efetiva de } \\
\text { material e trabalho }\end{array}$ \\
\hline JIT (Just in time) & $\begin{array}{l}\text { Alto volume, fabricação } \\
\text { repetitiva e montagem }\end{array}$ & $\begin{array}{l}\text { Minimização de tempos } \\
\text { de estabilização e inven- } \\
\text { tários, alta qualidade }\end{array}$ \\
\hline $\begin{array}{l}\text { Revisão periódica / } \\
\text { sequenciamento cí- } \\
\text { clico }\end{array}$ & Processo contínuo & $\begin{array}{l}\text { Minimização de sequên- } \\
\text { cias dependentes de re- } \\
\text { configuração, alta capaci- } \\
\text { dade de utilização }\end{array}$ \\
\hline
\end{tabular}

Fonte: (Silver et al., 2016)

otimizada) pertencem a essa categoria. Elas pregam a eliminação de todo desperdício (inclusive de estoques) e a melhoria contínua. Essas filosofias foram complementadas com modelos matemáticos de maneira a ajudar os gestores a explicar sua operação, mas elas não são baseadas em modelos.

\subsection{5}

\section{As fases de um estudo sobre inventário}

Na condução de um estudo sobre o inventário de uma empresa, devem ser seguidas seis fases (Silver et al., 2016): considerações iniciais, análise, síntese, escolha entre alternativas, controle e avaliação. A seguir são detalhadas cada uma dessas etapas.

A primeira parte deve conceitualizar o problema e cobrir um número de questões organizacionais e estratégicas. Deve ser realizado a alinhamento da gestão de estoques com as diretrizes estratégicas. Devem ser avaliados quais os objetivos operacionais da empresa devem ser seguidos (se custo, qualidade, entrega, flexibilidade), a responsabilidade da gestão do inventário e do planejamento e scheduling da produção, a estrutura organizacional, a 
relação entre áreas operacional e comercial, o nível atual de inventário em termos monetários, a gestão corrente do inventário e se o estoque existente é realmente necessário - talvez seja possível eliminar estoque que só existe por razões históricas.

A segunda parte do estudo deve focar na coleta de dados e no entendimento detalhado das variáveis controláveis e não controláveis. Variáveis não controláveis são, por exemplo, o número de itens e o grau de sazonalidade. Controláveis são aquelas quantidades que podem ser manipuladas para determinado objetivo. Devem ser definidos os produtos que serão estudados e avaliado se os estoques dos mesmo são independentes, se a demanda e produção são determinísticas ou variáveis, e se existe sazonalidade ao longo do ano. Devem ser verificados os dados históricos disponíveis, como é realizada a medição do nível de serviço, a capacidade de armazenamento e sua localização ao longo do processo, os custos associados, a capacidade de produção das unidades, o grau de confiabilidade das unidades de processo e a frequência de revisão dos inventários.

Com a vasta quantidade de informações coletada na fase anterior, o próximo estágio destina-se à síntese. As relações entre objetivo, variáveis controláveis e não controláveis e as técnicas de controle são estabelecidas e modeladas. Uma função objetivo (matemática) em função das variáveis controladas é, em geral, o resultado dessa fase.

Uma vez que se tem a função objetivo ou que as relações entre objetivos estejam estabelecidas, é necessário que seja determinado um nível razoável para as configurações das variáveis de controle no modelo. Isso pode ser feito através de métodos de cálculo ou métodos de procura, por exemplo. Se a decisão é repetitiva, é desejável que sejam desenvolvidas regras matemáticas de decisão.

A fase de controle é focada na implementação das regras de decisão. Aqui deve-se garantir que o sistema de funções esteja funcionando de maneira adequada, em base tática ou pontual. Algumas outras questões a serem endereçadas dizem respeito à necessidade de treinamento do grupo que fará o controle, como as variáveis devem ser monitoradas, diferenciações de controle de acordo com o tipo de estoque e como são tratadas as exceções.

A última etapa é a de avaliação, ou medição do quanto o sistema proposto é efetivo. A comparação do antes e depois pode validar os modelos utilizados e fornecer ajustes aos pontos discrepantes. 


\section{2}

\section{Políticas de estoque}

O termo política de estoques é reservado para o sistema de controle de estoque (Silver et al., 2016) e indica quanto e quando encomendar estoques, assim como a frequência de colocação de pedidos (contínua ou periódica). A tabela 3.3 apresenta as principais políticas (Thome, 2018).

Tabela 3.3: Políticas de estoque

\begin{tabular}{|c|c|c|c|}
\hline Tipo & & Sigla & Regras de decisão \\
\hline $\begin{array}{l}\text { Revisão } \\
\text { tínua, } \\
\text { fixos }\end{array}$ & $\begin{array}{l}\text { con- } \\
\text { lotes }\end{array}$ & $(s, Q)$ & $\begin{array}{l}\text { Uma quantidade fixa } Q \text { é pedida sem- } \\
\text { pre quando a posição do estoques atinja } \\
\text { ou ultrapasse o nível de reposição } s \text {. }\end{array}$ \\
\hline $\begin{array}{l}\text { Revisão } \\
\text { tínua, } \\
\text { variáveis }\end{array}$ & $\begin{array}{l}\text { con- } \\
\text { lotes }\end{array}$ & $(s, S)$ & $\begin{array}{l}\text { Uma quantidade variável é pedida sem- } \\
\text { pre quando a posição de estoque atinge } \\
\text { o ponto de reposição } s \text {, elevando o esto- } \\
\text { que a um máximo, } S \text {. Devido ao fato de } \\
\text { que os estoques situam-se entre s e S, } \\
\text { esta política é também conhecida como } \\
\text { Min-Max. }\end{array}$ \\
\hline $\begin{array}{l}\text { Revisão } \\
\text { riódica, } \\
\text { variáveis }\end{array}$ & $\begin{array}{l}\text { pe- } \\
\text { lotes }\end{array}$ & $(R, S)$ & $\begin{array}{l}\text { Esta política é também conhecida como } \\
\text { política de ressuprimento: a cada } R \text { pe- } \\
\text { ríodos (ou a cada revisão periódica do } \\
\text { estoque) é pedida uma quantidade su- } \\
\text { ficiente para aumentar a posição do es- } \\
\text { toque para } S \text {. }\end{array}$ \\
\hline $\begin{array}{l}\text { Revisão } \\
\text { riódica, } \\
\text { variáveis }\end{array}$ & $\begin{array}{r}\text { pe- } \\
\text { lotes }\end{array}$ & $(R, s, S)$ & $\begin{array}{l}\text { É uma combinação das políticas }(s, S) \text { e } \\
(R, S) \text {. A cada período fixo } R \text {, verifica- } \\
\text { se a posição de estoque. Se estivar no } \\
\text { ponto de ressuprimento s, ou abaixo, } \\
\text { pede-se uma quantidade suficiente para } \\
\text { que a posição de estoque atinja o nível } \\
\text { máximo } S \text {. }\end{array}$ \\
\hline
\end{tabular}

Fonte: (Thome, 2018)

\section{3}

\section{Estoque de produto intermediário e pulmão entre processos}

Os estoques intermediários possuem papel importante nos processos de manufatura. Esses sistemas, também conhecidos como linhas de produção, podem ser simplificadamente representados por uma série de máquinas (ou processos ou estágios - nesse texto tratados como sinônimos), entre os quais 
pode existir um pulmão amortecedor para produto intermediário. A figura 3.4 representa simplificadamente um sistema de 5 estágios (Dallery \& Gershwin, 1992) .

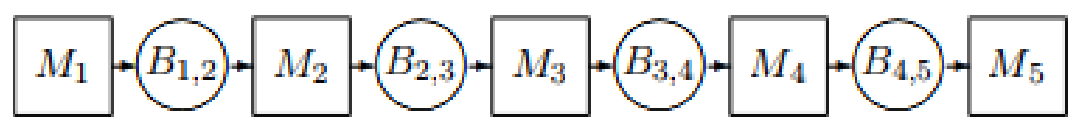

Figura 3.4: Linha de manufatura com 5 máquinas

Fonte: (Dallery \& Gershwin, 1992)

As máquinas são numeradas de 1 até $\mathrm{K}$,onde $\mathrm{K}$ é o número de máquinas do sistema. Existem então $K-1$ pulmões amortecedores de produto intermediário e o pulmão entre as máquinas $M_{i}$ e $M_{i+1}$ é $B_{i, i+1}$. Toda vez que a máquina $M_{i}$ processa alguma material, o nível do estoque em $B_{i-1, i}$ é reduzido, enquanto o nível em $B_{i, i+1}$ é elevado. Por outro lado se a máquina $M_{i}$ falha ou leva muito tempo para processar um material o nível em $B_{i-1, i}$ aumenta, enquanto o nível em $B_{i, i+1}$ diminui. Dependendo da duração, o $B_{i-1, i}$ pode ficar lotado e $B_{i, i+1}$ completamente vazio. Nessa condição, os vizinhos de $M_{i}$ ficam impedidos de operar. $M_{i}$ não tem carga para processar enquanto $M_{i+1}$ se encontra bloqueado, sem espaço para recebimento da sua produção.

A função do pulmão de amortecimento é desassociar dois estágios e dar a eles algum grau de atuação independente (Conway et al., 1988). Assim, se uma máquina está sujeita a uma interrupção (uma falha ou um longo período para processamento), o processo à montante ainda pode operar enquanto tiver espaço no buffer à montante. Raciocínio análogo é possível para o processo à jusante, que poderá continuar operando enquanto houver carga no buffer à jusante. Quando não existe o pulmão intermediário entre os estágios de produção, esses devem estar perfeitamente sincronizados para operar eficientemente.

Muitas vezes a proteção oferecida pelos buffers intermediários é questionada, já que pode ser contra produtivo aliviar os efeitos danosos da falta de confiabilidade e da variabilidade dos processos, não atuando na causa básica do problema. No entanto, existe uma quantidade e uma locação apropriada que aumenta a eficiência do processo, o que foi demonstrado por (Conway et al., 1988). 
A frequência com a qual ocorre o bloqueio da máquina e a parada por falta de carga dependem da variabilidade dos tempos de processamento das máquinas adjacentes. Da maneira similar, o poder do buffer de produto intermediário para aliviar esses problemas também depende da variabilidade. Adicionalmente, máquinas que param devido a falhas aleatórias produzem o mesmo efeito que o aumento do tempo de processamento e comportamento análogo para o buffer é esperado.

Linhas de produção são em geral desbalanceadas. Isso quer dizer que existe um processo gargalo, e que esse apresenta o maior tempo de processamento. A utilização de buffer antes e depois desse processo se mostra eficaz, sendo que à montante tende a ficar cheio e à jusante, vazio.

\section{4}

\section{Revisão sistemática sobre gestão de estoques intermediários}

A revisão sistemática foi realizada de acordo com os oito passos propostos por (Thomé et al., 2016) e descritos no Capítulo 2, de Metodologia.

Foi realizada uma análise de publicações por periódico, conforme apresentado na figura 3.5, com grande relevância para o International Journal of Production Economics e o The International Journal of Advanced Manufacturing Technology. Apesar disso, há diversidade nos periódicos já que para os 15 artigos, 8 periódicos diferentes foram encontrados.

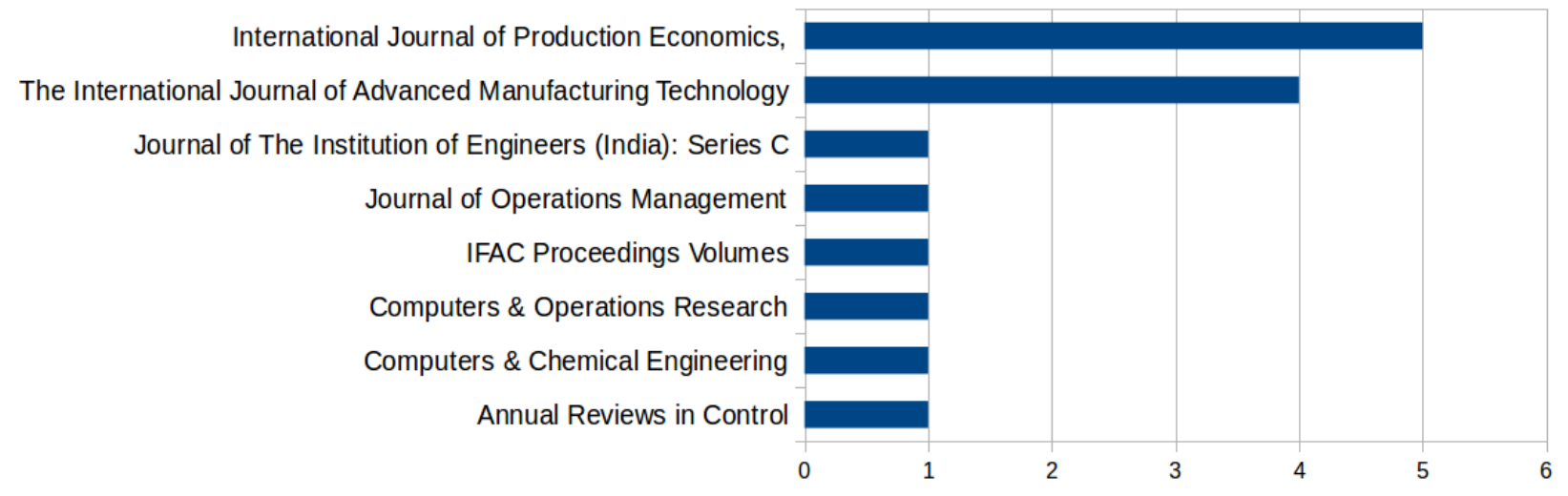

Figura 3.5: Distribuição de artigos selecionados por periódico

Fonte: Elaboração própria

A figura 3.6 apresenta a distribuição dos artigos de acordo com o framework de estratégia de modelagem proposto por (Silver et al., 2016) e 
discutida anteriormente nesse trabalho. É possível perceber a maior recorrência de estudos do tipo de minimização de inventário com baixa modelagem.

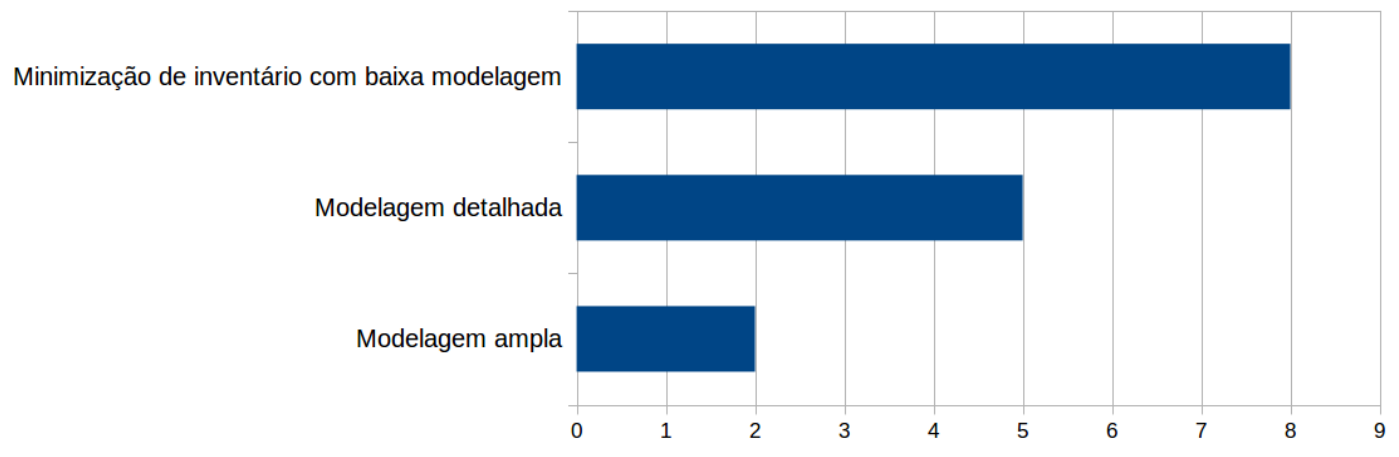

Figura 3.6: Número de artigos por tipo de modelagem Fonte: Elaboração própria

Um diagnóstico de 19 plantas da indústria de processo foi realizado por (Dennis \& Meredith, 2000), de maneira a identificar as principais diferenças nos sistemas de transformação. Através da técnica de clusterização, as indústrias foram separadas em sete subgrupos: (1) loja de trabalho de processo - process job shop, (2) batelada rápida, (3) mistura customizada, (4) híbrido de estoque, (5) híbrido customizado, (6) contínuo multi-estágio, (7) contínuo rígido. Foi demonstrado que as diferenças entre os tipos de indústria de processo são bem caracterizadas pela diversidade de produtos, movimentação de materiais, equipamentos e tempo de campanha. Nesse artigo concluíram que, além dos ganhos acadêmicos, o estudo traz ganhos gerenciais, uma vez que é possível que as empresas reconheçam mais facilmente a quais tipos de indústrias se assemelham, encorajando-as a olhar para fora, em busca de aumento de eficiência e efetividade, inclusive em relação à gestão de inventários.

De maneira semelhante, (Demeter \& Golini, 2014) também incentivaram os gestores a entenderem as suas configurações de estoques para desenvolvimento de estratégias eficazes de redução do inventário. Assim, realizaram uma pesquisa do tipo survey com indústrias montadoras em 2001, 2005 e 2009 com o objetivo de verificar quais as principais configurações encontradas para o inventário de matéria prima, produtos intermediários e produtos finais e quais fatores explicam as diferentes configurações. Foram identificados 5 clusters nesse tipo de indústria com configurações de estoques do tipo ABB, AAA, $\mathrm{BBA}, \mathrm{BAB}, \mathrm{BBB}$ onde $\mathrm{A}$ denota alto, $\mathrm{B}$ baixo, e a primeira letra representa o estoque de matéria prima, a segunda o estoque de produto intermediário, e a 
terceira estoque de produto final. Assim, ABA denota alto estoque de matéria prima, baixo estoque de produto intermediário e alto estoque de produto final, por exemplo. As seguintes características foram encontradas para os clusters:

- $A B B$ - produção de especialidades no upstream;

- $A A A$ - baixa integração de comunicação;

- BBA - produção em massa inovadora;

- $B A B$ - produção customizada de alto valor agregado;

- $B B B$ - produção focada na gestão lean.

Foi comprovado que as configurações adotadas pelas empresas em termos de nível de cada tipo de inventário se mantiveram estáveis ao longo do período analisado. Além disso, concluíram também que as características de produção são fatores importantes por trás dos níveis de inventário e a proporção entre os mesmos, mais importantes até que as características da cadeia de suprimento. Em relação às características da cadeia de suprimento, o compartilhamento de informações com clientes pode ajudar a adequar os níveis dos inventários, o que suporta a ideia de que a informação pode substituir ao menos parte do inventário.

Uma revisão bibliográfica relativa ao sistema JIT-KANBAN foi realizada por (Sendil Kumar \& Panneerselvam, 2007) para verificação do utilização das ferramentas. O método JIT (just in time) tem como objetivo a minimização (e em último estágio a eliminação) de todas as formas de desperdícios. É enfatizado o "conceito zero": zero defeito, zero fila, zero inventário. O sistema visa a garantia do suprimento da parte certa, no momento certo, no local certo. O método da produção empurrada é substituído pela produção puxada, no qual o inventário de produtos intermediários pode ser mais eficientemente controlado e gerido. Uma das ferramentas utilizadas é o sistema kanban, que possibilita o sequenciamento da produção multi-estágio e o controle do inventário.

Nessa revisão, os autores concluíram que grande parte das pesquisas estava voltada para teoria empírica, flow shop, simulação de variabilidade e seus efeitos. Os objetivos mais frequentemente almejados nas pesquisas foram: desenho de sistema kanban, comportamento de desempenho, sequenciamento e scheduling.

A filosofia lean foi mais frequentemente aplicada à manufatura discreta do que na indústria de processo contínuo, mas também apresenta ganhos 
para a segunda, conforme apontado por (Abdulmalek \& Rajgopal, 2007). Em um estudo de caso em uma acearia, após mapeamento da cadeia de valor, foi desenvolvido um modelo e realizada uma simulação com o objetivo de contrastar os cenários de "antes" e "depois" da aplicação das ferramentas lean. Os autores apontaram a importância da apresentação dos resultados para esclarecimento ao corpo gerencial dos ganhos potenciais das mudanças, tais como redução do lead time e do estoque de produto intermediário.

Foi comprovado também por (Tanco et al., 2013) que a filosofia lean pode ser aplicada em vários setores da indústria, utilizando como exemplo um estudo de caso na indústria alimentícia. São utilizadas várias técnicas e análises, como mapeamento de fluxo de valor, diagramas de espaguete, equilíbrio de trabalho e simulação de eventos discretos. O mapeamento do fluxo de valor futuro também foi realizado, onde as ideias de melhoria identificadas em todo o projeto foram consolidadas, com ganhos especiais em relação ao lead time e à eficiência no ciclo de trabalho.

O mapeamento da cadeia de valor para uma indústria de manufatura foi realizado por (Jeyaraj et al., 2013) e, após aplicação de ferramentas da filosofia lean, ganhos expressivos no tempo de TAKT (ritmo do proceseso de manufatura), no tempo de processamento e no estoque de produtos intermediários foram observados.

A análise de simulação multivariada do nivelamento da produção (heijunka) foi realizada por (Korytkowski et al., 2013) para uma linha de montagem de microeletrônicos. Heijunka é uma das ferramentas lean usada para estabilizar o sistema de manufatura, através de um sequenciamento de produção cíclica que cria regularidade na produção e simplicidade de coordenação. A técnica de simulação foi aplicada de maneira a a avaliar a performance do sistema de manufatura, com objetivo de reduzir o estoque intermediário e o tempo de processamento.

Uma discussão e análise sobre a integração dos sistemas de execução manufatura e a metodologia Seis Sigma foi apresentada por (Hwang, 2006). O sistema pode se conectar com equipamentos de automação e realizar o registro de informações relevantes automaticamente controlando, por exemplo, a qualidade/quantidade de estoque intermediário, a programação de produção e a manutenção de equipamentos e instrumentos, etc. As fases do ciclo DMAIC (definir, medir, analisar, melhorar - (improve) e controlar) são analisadas, integrando o sistema de execução manufatura e a metodologia Seis Sigma, com objetivo de redução de custos operacionais - inclusive através da redução 
do estoque intermediário.

Em uma revisão da evolução do scheduling no ambiente industrial, no qual no problema multi-critério é considerado o controle do estoque intermediário, (Proth, 2007) concluiu que schedulings dinâmicos estão tomando o lugar dos estáticos. Assim, atribuição em tempo real em sistemas de produção é um ponto crucial na produção e deve chamar a atenção de pesquisadores.

A consideração do nível de estoques intermediários em funções objetivos de redução de custo total foi realizada em diversos artigos. Uma formulação de programação não linear para cálculo do estoque de segurança considerando a dependência não linear entre utilização dos recursos, lead times e estoques de segurança foi apresentada por (Orcun et al., 2009). A função objetivo considerou o estoque de produtos intermediários e os custos a eles associados.

Os benefícios da coordenação entre dois estágios adjacentes em um sistema de produção foram demonstrados por (Manoj et al., 2012). O objetivo da primeira etapa foi minimizar o custo de estoque medido pela soma do tempo de processamento, e o segundo estágio foi minimizar o custo de atraso e o custo de resequenciamento no buffer. O desempenho do sistema foi medido pela soma dos custos associados a ambos os estágios. Foi demonstrado que o problema é do tipo NP-difícil e que os problemas individuais podem ser resolvidos em tempo polinomial. Foi projetado um algoritmo genético que forneceu soluções ideais rapidamente, e estudos numéricos revelaram que a economia de custos fornecida pelo scheduling coordenado dos estágios é relevante.

Uma alocação quase ótima de buffers para um sistema de remanufatura com paradas previstas da unidade foi apresentada por (Aksoy \& Gupta, 2011). Para isso, foram considerados na função objetivo, os custos relativos ao estoque intermediário, sendo proposto um algoritmo para minimização dos custos totais. Com o aumento do número de buffers no sistema, aumentou-se também o estoque intermediário do sistema, o que afetou diretamente os custos operacionais e o desempenho.

Em técnicas avançadas de controle de inventário, foram encontrados artigos que utilizam os princípios da teoria de controle. Uma analogia aos fluidos foi apresentada por (Schwartz \& Rivera, 2010), com aplicação do controle por modelo interno e do controle por modelo preditivo de maneira a gerar uma série de políticas de decisão cada vez mais sofisticadas para o gerenciamento de estoques.

Analogamente, (Wang et al., 2007) examinaram a aplicação do controle por modelo preditivo, técnica de controle avançado utilizado nas indústrias de 


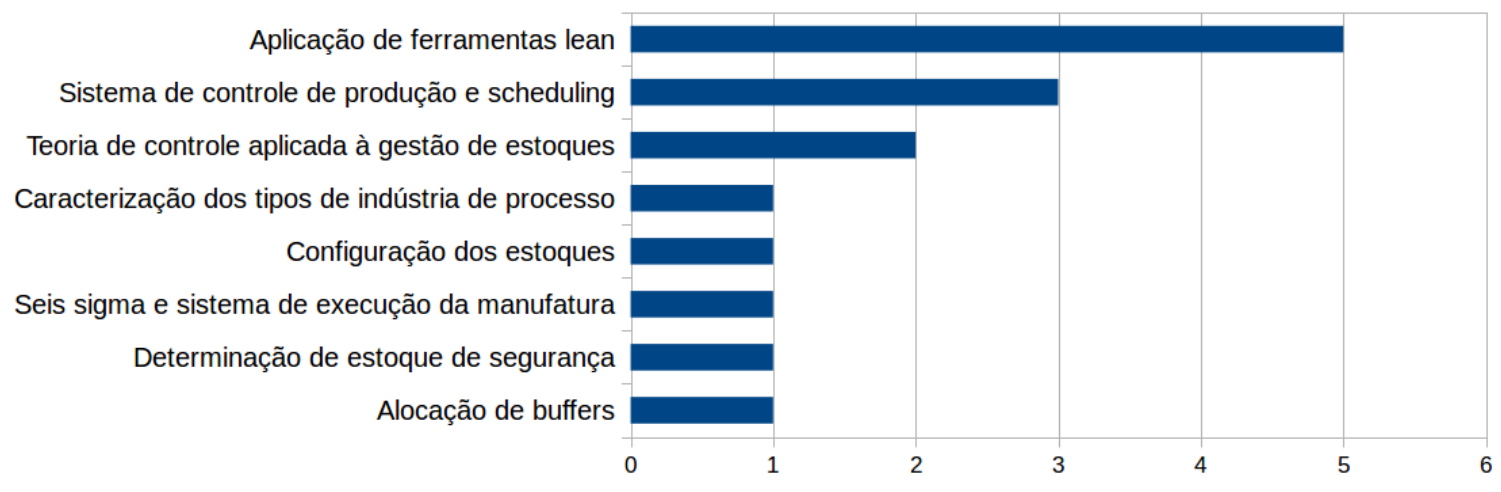

Figura 3.7: Distribuição de artigos por tema Fonte: Elaboração própria

processo, para solução de problemas de gerenciamento da cadeia de suprimento existentes na fabricação de semicondutores. O principal objetivo do trabalho foi demonstrar a utilidade do modelo como uma política de decisão tática que visa alcançar a excelência operacional. Também nesse caso foi utilizada uma analogia aos fluidos para descrever a dinâmica das cadeias.

Por fim, (Wikner et al., 2017) apresentaram um sistema de controle de produção com foco em inventário e pedidos. O modelo é baseado na previsão, sendo as decisões de produção tomadas considerando-se as metas de estoque.

A figura 3.7 mostra a distribuição dos artigos de acordo com o tema abordado. É possível concluir que a filosofia lean ainda teve bastante foco nas pesquisas realizadas nos últimos anos.

\section{5}

\section{Esquemas de Refino}

A figura 3.8 mostra a cadeia de suprimento da indústria do óleo (C. Lima et al., 2016). No upstream encontram-se a exploração/produção de petróleo e o transporte do óleo cru. O processo de refino, foco desse trabalho, encontrase em uma fase intermediária entre a produção do petróleo e a distribuição dos seus derivados. Na sequência, os produtos do petróleo são vendidos para a distribuição primária, podendo passar pela secundária até chegar ao mercado local.

Pode-se dizer que o refino é um conjunto de várias etapas de operações que abrangem diversos processos físicos e químicos, cujo objetivo é a produção de derivados finais para consumo. Dentre esses derivados, estão um grande 


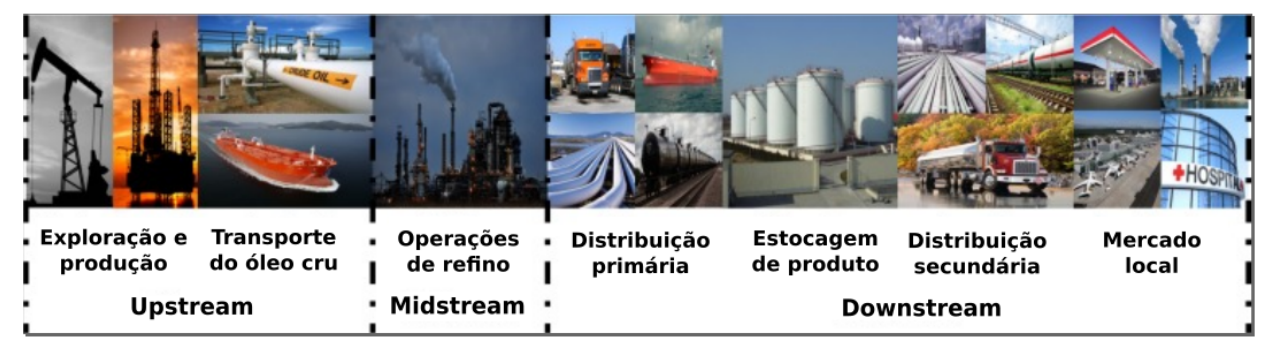

Figura 3.8: Cadeia de suprimento da indústria de óleo Fonte: (C. Lima et al., 2016)

espectro de produtos, dos quais se destacam: gasolina, diesel, asfalto, óleo combustível, gás liquefeito de petróleo (GLP) e querosene de aviação.

O processo se inicia com o recebimento do petróleo nos tanques da refinaria. Após preparo e certificação, o petróleo é enviado para a unidade de destilação atmosférica. Devido às diferentes temperaturas de ebulição, diversas frações podem ser separadas como gás liquefeito de petróleo (GLP), nafta, querosene intermediário, diesel intermediário e resíduo atmosférico, por exemplo (API, 2012). É comum a presença de uma unidade de destilação a vácuo após a unidade de destilação atmosférica para processamento do resíduo atmosférico e separação das frações de gasóleos e resíduo de vácuo.

Como existe maior demanda por produtos destilados como gasolina e diesel, a conversão de líquidos pesados em leves é atrativa (API, 2012). Dessa maneira, os produtos pesados provenientes das destilações são processados nas unidades de conversão, que tem como objetivo a quebra das longas cadeias de hidrocarbonetos em moléculas menores (produtos mais leves). As frações de gasóleo são em geral enviadas para as unidades de craqueamento catalítico, enquanto o resíduo de vácuo segue para a unidade de coque.

O óleo cru contém naturalmente uma série de contaminantes, como enxofre, nitrogênio e metais pesados, que são indesejados nos motores a óleo. Os processos de tratamento tem por objetivo a remoção desses contaminantes do produto final a ser comercializado. É possível assim o hidrotratamento de frações como a nafta, diesel intermediário, gasóleo e querosene para especificação e posterior mistura para composição do produto final.

Uma divisão simplificada dos diferentes tipos de unidade, suas principais características e exemplos, apresentada por (M. M. F. Oliveira, 2014), é mostrada na tabela 3.4. É possível perceber que no processo de refino dos produtos de petróleo, vários tipos de unidades podem estar envolvidos desde 
a destilação do petróleo até a obtenção do produto final.

Tabela 3.4: Principais características de cada tipo de unidade de processo em uma refinaria

\begin{tabular}{|c|c|c|c|}
\hline $\begin{array}{l}\text { Tipo de } \\
\text { Unidade }\end{array}$ & Função & $\begin{array}{l}\text { Fundamento físico- } \\
\text { químico }\end{array}$ & Exemplos \\
\hline $\begin{array}{l}\text { Separação } \\
\text { física }\end{array}$ & $\begin{array}{l}\text { Separar a } \\
\text { carga } \\
\text { processada } \\
\text { em diferentes } \\
\text { componentes }\end{array}$ & $\begin{array}{l}\text { Diferença de solubili- } \\
\text { dade entre os compo- } \\
\text { nentes da carga pro- } \\
\text { cessada }\end{array}$ & $\begin{array}{l}\text { Destilação Atmos- } \\
\text { férica e Destilação a } \\
\text { Vácuo }\end{array}$ \\
\hline \multirow{3}{*}{ Conversão } & \multirow{3}{*}{$\begin{array}{l}\text { Alterar qui- } \\
\text { micamente a } \\
\text { composição } \\
\text { da corrente } \\
\text { de entrada }\end{array}$} & $\begin{array}{l}\text { Quebra das cadeias } \\
\text { moleculares via calor }\end{array}$ & $\begin{array}{l}\text { Coqueamento } \\
\text { Craqueamento } \\
\text { Térmico Brando }\end{array}$ \\
\hline & & $\begin{array}{l}\text { Quebra das cadeias } \\
\text { moleculares via calor } \\
\text { e presença de catalisa- } \\
\text { dor }\end{array}$ & $\begin{array}{l}\text { Craqueamento Ca- } \\
\text { talítico }\end{array}$ \\
\hline & & $\begin{array}{l}\text { Síntese ou alteração } \\
\text { da cadeia molecular }\end{array}$ & $\begin{array}{l}\text { Reforma e Alcoila- } \\
\text { ção }\end{array}$ \\
\hline Tratamento & $\begin{array}{l}\text { Retirar impu- } \\
\text { rezas e especi- } \\
\text { ficar qualida- } \\
\text { des }\end{array}$ & $\begin{array}{l}\text { Reação com ambiente } \\
\text { rico em hidrogênio e } \\
\text { em alta temperatura e } \\
\text { pressão }\end{array}$ & $\begin{array}{l}\text { hidrotratamento de } \\
\text { diesel, } \\
\text { Hidrotratamento } \\
\text { de nafta }\end{array}$ \\
\hline
\end{tabular}

Existem diversas configurações possíveis para uma refinaria. A figura 3.9 apresenta uma delas. Após a unidade de destilação, produtos leves como gás combustível, GLP são gerados e podem ser consumidos internamente (gás combustível), ou estocados em esferas para venda (GLP e butano).

Produtos de corte médio, como naftas intermediárias, diesel intermediário, e querosene são em geral hidrotratados para posteriormente comporem o pool de produto final. Produtos pesados como gasóleo, resíduo atmosférico e resíduo de vácuo podem ser carga de unidades de conversão como craqueamento catalítico e coqueamento retardado. Os produtos de corte médio gerados por essas unidades, após tratamento, também compõem os produtos finais da refinaria, como diesel e gasolina. A tabela 3.5 mostra as correntes mais frequen- 


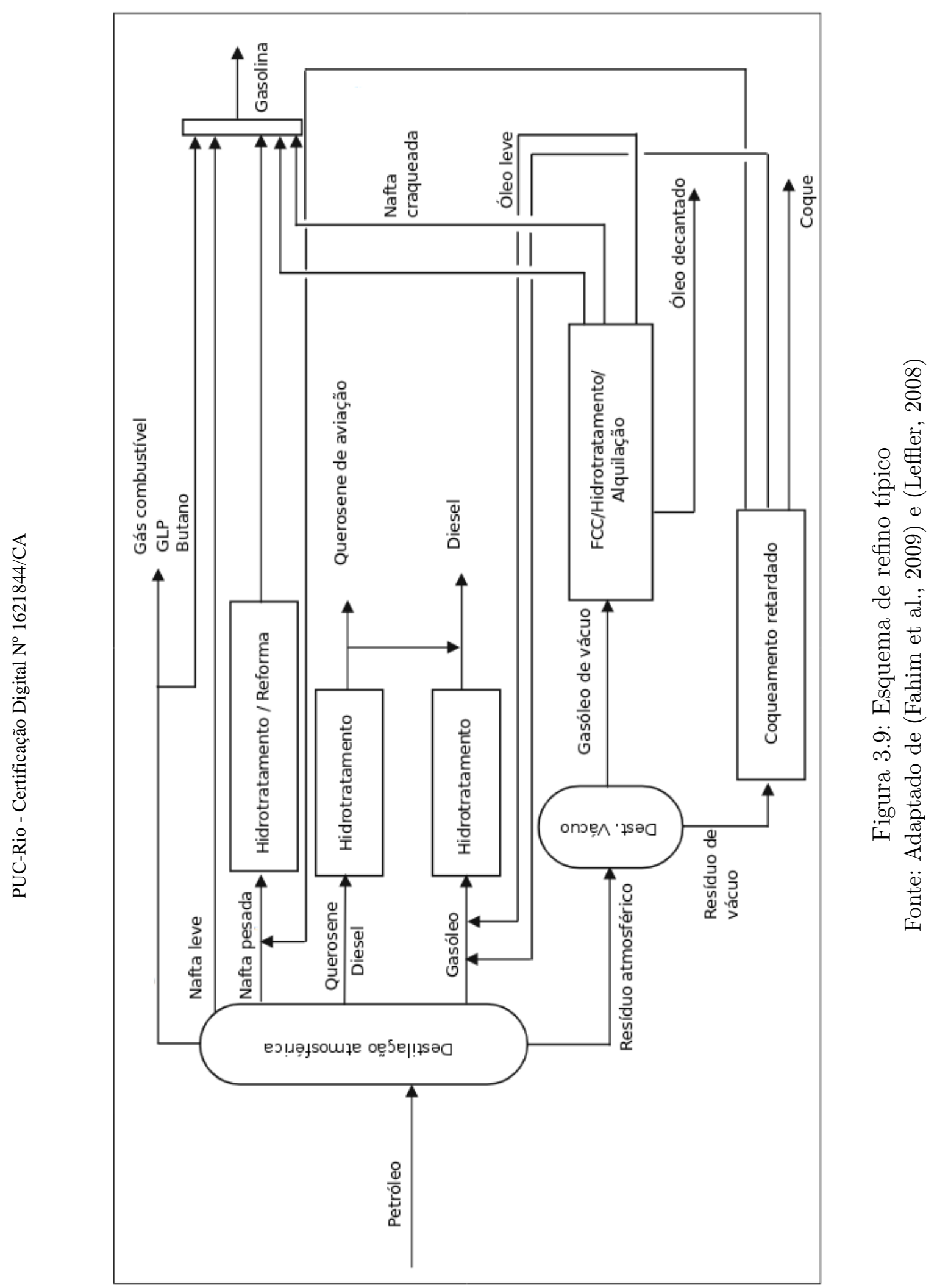


temente utilizadas como carga ou produção das unidades, baseado em (Fahim et al., 2009) e (Leffler, 2008).

Para a destilação o petróleo é a carga e os cortes obtidos podem ser leves (gás combustível e gás liquefeito de petróleo), médios (diesel, nafta e gasóleo), e pesado (resíduo atmosférico). Já para a o craqueamento, a carga típica é o gasóleo, com produção de nafta craqueada, óleo leve de reciclo, óleo decantado e gás liquefeito de petróleo. A carga das unidades de coqueamento retardado é em geral o resíduo de vácuo, e sua produção a nafta, gasóleo, coque e GLP. No caso das unidades de hidrotratamento, a produção das unidades são as suas cargas tratadas.

Tabela 3.5: Carga e produção das unidades de processo

\begin{tabular}{|c|c|c|}
\hline Unidade & Carga & Produto \\
\hline Destilação atmosférica & Petróleo & $\begin{array}{l}\text { Gás combustível, } \\
\text { GLP, nafta, querosene, } \\
\text { diesel leve, diesel pesado, } \\
\text { resíduo atmosférico }\end{array}$ \\
\hline Destilação a vácuo & Resíduo atmosférico & $\begin{array}{l}\text { Gasóleo leve, gasóleo médio, } \\
\text { gasóleo pesado, resíduo } \\
\text { de vácuo }\end{array}$ \\
\hline Craqueamento catalítico & Gasóleo & $\begin{array}{l}\text { GLP, nafta craqueada, } \\
\text { óleo leve de reciclo, } \\
\text { óleo decantado }\end{array}$ \\
\hline Coqueamento & Resíduo de vácuo & $\begin{array}{l}\text { GLP, nafta de coque, } \\
\text { gasóleo de coque, coque }\end{array}$ \\
\hline Hidrotratamento & $\begin{array}{l}\text { Diesel leve, diesel pesado, } \\
\text { nafta craqueada, nafta leve, } \\
\text { nafta pesada, querosene, } \\
\text { gasóleo }\end{array}$ & $\begin{array}{l}\text { Diesel hidrotratado, nafta } \\
\text { hidrotratada, querosene } \\
\text { hidrotratada }\end{array}$ \\
\hline
\end{tabular}

Fonte: Adaptado (Fahim et al., 2009) e (Leffler, 2008)

Salvo o gás combustível, todas as correntes listadas na tabela 3.5 podem ser armazenadas em tanques atmosféricos ou pressurizados e são consideradas derivados intermediários. Além dos produtos que são carga de unidades de processos, há nas refinarias estoques intermediários que servem como componentes de produtos finais. A tabela 3.6 apresenta como os derivados intermediários podem compor tipicamente os principais produtos finais. Vale notar que o mesmo intermediário pode servir como carga de unidade ou como componente de produto final para um ou mais produtos. Ressalta-se também que a receita 
Tabela 3.6: Componentes dos principais produtos de petróleo

\begin{tabular}{ll} 
Produto & Principais componentes \\
\hline Gasolina & $\begin{array}{l}\text { Nafta craqueada, nafta hidrotratada, nafta } \\
\text { de destilação }\end{array}$ \\
\hline Diesel & Diesel hidrotratado, diesel leve, nafta pesada \\
\hline Óleo combustível & $\begin{array}{l}\text { Resíduo atmosférico, óleo decantado, resíduo } \\
\text { de vácuo }\end{array}$ \\
\hline Querosene de aviação & $\begin{array}{l}\text { Querosene intermediária, querosene hidro- } \\
\text { tratada, nafta pesada }\end{array}$ \\
\hline
\end{tabular}
Fonte: Oliveira (M. M. F. Oliveira, 2014)

para produção dos produtos e para a carga de unidades pode variar de acordo com o esquema de refino.

A composição típica da gasolina contem diferentes tipos de nafta, com grande participação da nafta craqueada, que confere qualidades específicas ao produto. No caso do diesel, diferentes cortes de diesel interno são utilizados, e a escolha dos componentes depende principalmente do teor de enxofre necessário para a certificação do produto final. Correntes pesadas são misturadas para obtenção do óleo combustível. A querosene de aviação, por sua vez, é produzida através da mistura de componentes médios, como cortes de querosene intermediária. Conforme citado anteriormente, além dos produtos listados, outros podem ser produzidos pelas refinarias. Refinarias com esquema de refino adequado à produção de lubrificantes, por exemplo, possuem correntes intermediários específicas para essa finalidade.

Dessa maneira, são considerados estoques intermediários em uma refinaria todas as cargas e os componentes elencados nas tabelas 3.5 e 3.6. Outras correntes intermediárias incluem resíduo de unidades e produtos fora de especificação. O resíduo de unidades é produzido, de forma geral, em momentos de instabilidade operacional, em drenagens de produtos para remoção de água e na recuperação de óleo dos sistemas de efluentes e alívio. Os produtos fora de especificação são em sua maioria frutos de parada e partida de unidades, momentos nos quais a produção não encontra-se enquadrada para ser destinada aos produtos finais.

A gestão adequada dos estoques intermediários em uma refinaria deve considerar os custos relacionados a cada tipo de estoque, bem como o custo da sua falta, que podem impactar tanto a produção de unidades quanto o atendimento ao mercado. 


\section{4}

\section{Estudo de caso}

A empresa analisada no estudo de caso atua no setor de óleo e gás, em atividades de exploração e produção, refino, comercialização, transporte, petroquímica, distribuição de derivados e gás natural. No ramo de processamento de petróleo, a empresa conta com 13 refinarias e 1 unidade de industrialização de xisto, e produção estimada de 1 milhão 800 mil barris por dia de produtos.

A área de downstream da empresa é divida em diferentes gerências executivas, que para o fim desse trabalho serão detalhadas três: a Logística, a Industrial e a Comercial. Um organograma simplificado é apresentado na figura 4.1 .

Logística: Responsável por garantir uma gestão integrada da operação de downstream entre os processos industriais e os mercados consumidores, maximizando rentabilidade do mix de produtos e minimizando custos e perdas. A área de planejamento operacional está sob gestão dessa gerência executiva. É responsável pela indicação do planejamento otimizado das cargas, alocações

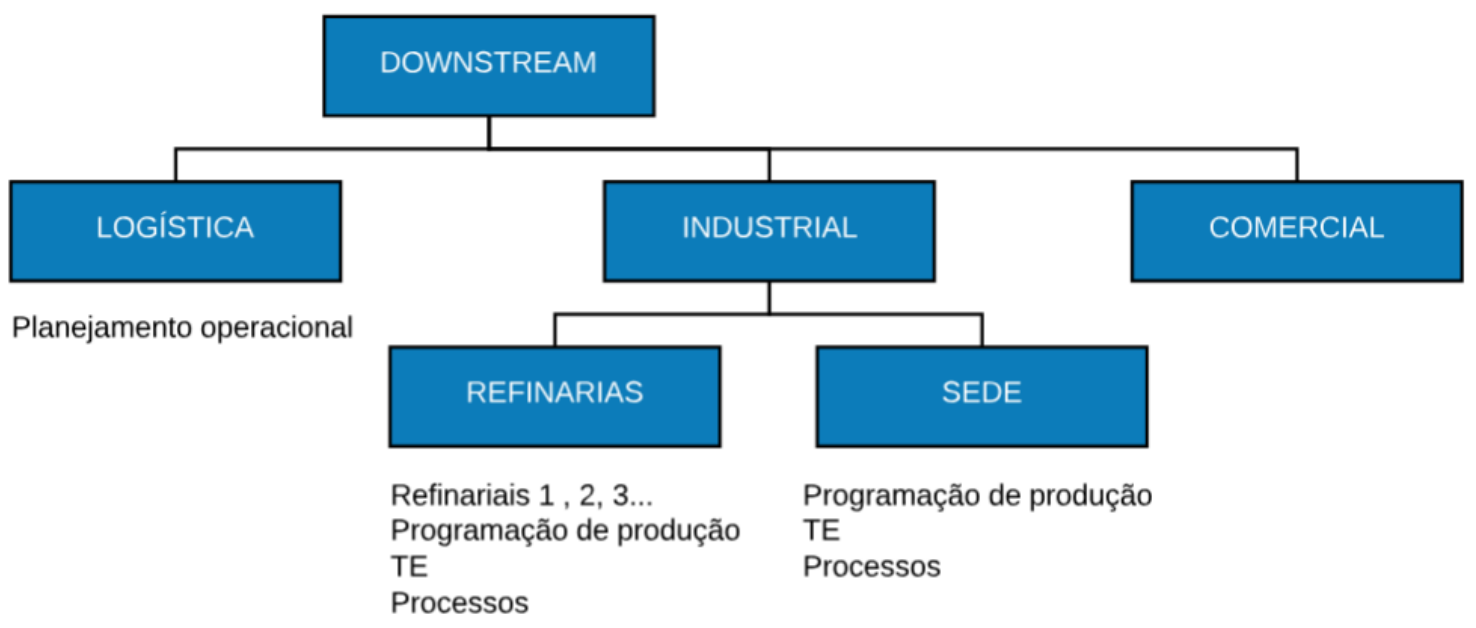

Figura 4.1: Organograma simplificado da empresa Fonte: Elaboração própria 
de produto e mercados a serem atendidos por cada refinaria. As premissas consideradas para a otimização são recebidas da área Industrial e da área Comercial.

Industrial: Responsável pelo planejamento, gestão, organização e implementação das políticas, estratégias e diretrizes, de forma integrada, na área Industrial, compreendendo gestão das Unidades de Operações (refinarias e unidade de processamento de xisto), visando otimizar e maximizar o processo produtivo de modo a garantir o maior valor agregado aos produtos e a melhor rentabilidade para a empresa, tendo como base os valores de segurança, meio ambiente e saúde, e os princípios de responsabilidade social. Abaixo da gerência executiva da Industrial encontram-se todas as refinarias e áreas de suporte da sede. A sede atua como um espelho das áreas operacionais, com departamentos responsáveis pelos processos, transferência e estocagem e programação de produção.

Comercial: Responsável por planejar, executar e avaliar as atividades de comercialização e marketing de petróleo e seus derivados, biocombustíveis e petroquímicos, estabelecendo preços e desenvolvendo produtos e serviços com base nas necessidades dos clientes, de forma a garantir a colocação da produção no mercado, seja produção interna ou por meio de importação.

A gestão dos estoques intermediários da empresa é realizado pela área Industrial, na sede. Na seguinte seção é apresentado um breve histórico do desenvolvimento interno do assunto nos últimos anos.

\section{1}

\section{Histórico}

De acordo com os registros documentais, em março de 2013 o assunto de gestão dos estoques intermediários chegou oficialmente à pauta da empresa através da criação de um grupo de trabalho multidisciplinar que contava com a participação de um representante de cada refinaria (do departamento de programação de produção), da área de logística, da área comercial, de cada um dos processos de refino e coordenação pela área operacional da sede de transferência e estocagem.

O objetivo do grupo foi o estabelecimento de uma política para estoques intermediários semi-acabados e cargas de unidades, considerando a definição de indicadores e práticas de gestão com foco na otimização destes recursos. Em julho de 2013, foi realizada apresentação sobre a iniciativa para o alto escalão, com os resultados iniciais da análise realizada pelo grupo. A situação corrente 
foi detalhada, bem como o potencial de redução dos estoques na faixa de $25 \%$, além de ganho esperado em relação à redução do uso da tancagem em torno de $20 \%$.

A expectativa de redução dos estoques estava baseada na mudança de paradigma. O grupo gestor entendeu que a visão deveria passar de

"O estoque intermediário serve para absorver as variabilidades internas da unidade, visando otimizar a produção e a logística. O custo financeiro do estoque intermediário não entra nas análises de otimização e lucratividade" para

"O estoque intermediário é um insumo caro, que imobiliza capital da empresa e carrega o custo de oportunidade deste capital imobilizado. Todo estoque intermediário existente deve ser economicamente justificado".

O grupo concluiu que deveriam ser mantidos estoques proporcionais a um dia de produção do derivado para os componentes de mistura, respeitando o percentual de participação no derivado final e estoques inferiores a dois dias de carga da unidade de craqueamento catalítico, ou um dia de carga para as demais unidades. Qualquer estoque intermediário que a unidade operacional desejasse manter, fora do que estava estabelecido nas diretrizes apresentadas, deveria ser justificado economicamente com envio da memória de cálculo para a área de coordenação, que realizaria a aprovação.

Ao final de 2013, foi proposto pelo grupo criação de indicador para acompanhamento dos estoques intermediários nas refinarias, cuja identidade está apresentada na 4.1. O indicador ficou sob a coordenação da área de transferência e estocagem na sede e sob a responsabilidade da programação de produção nas refinarias.

Foram propostas metas que deveriam ser perseguidas pelas unidades operacionais. As metas eram individualizadas por refinaria e os estoques intermediários eram todos contabilizados em um único valor agregado. Ou seja, a meta não era discretizada para cada tipo de produto ou classe. A definição da meta teve como base de cálculo um estudo de comparação (benchmarking) realizado por entidade externa com resultados de refinarias ao redor de todo o mundo. 
Tabela 4.1: Identidade do indicador de estoques intermediários

\begin{tabular}{ll} 
Descrição & Estoque de Produtos Intermediários \\
\hline Unidade Medida & $\mathrm{m}^{3}$ \\
\hline Periodicidade & Mensal \\
\hline Definição & Mede o estoque de intermediários \\
\hline Objetivo & $\begin{array}{l}\text { Redução dos estoques intermediários até } \\
\text { atingir os valores determinados pela política } \\
\text { de estoques intermediários }\end{array}$ \\
\hline Fonte & Banco de dados de movimentações e estoque \\
\hline Orientação Análise & $\begin{array}{l}\text { Será considerado para o cálculo da média } \\
\text { mensal o estoque total a } 20^{\circ} \mathrm{C} \text { do fechamento } \\
\text { de cada dia do mês }\end{array}$ \\
\hline Referencial Comparação & $\begin{array}{l}\text { Primeiro quartil apresentado pelo estudo ex- } \\
\text { terno com refinarias de todo mundo }\end{array}$ \\
\hline Data de fechamento & Dia 10 do mês seguinte \\
\hline & Fonte: Elaboração própria
\end{tabular}

Três ferramentas de apoio à decisão foram desenvolvidas. A primeira delas era utilizada para análise dos estoques, através de aquisição dos dados históricos. Era possível a segregação do estoque por refinaria, classe de produto ou tipo de produto.

A segunda ferramenta tinha como objetivo a aquisição dos preços correntes de cada tipo de produto intermediário. Já a terceira ferramenta desenvolvida foi utilizada para cálculo do período a partir do qual a manutenção do estoque já não era mais atrativa.

Adicionalmente, foi realizado estudo de benchmarking interno entre as unidades operacionais e verificadas as principais divergências entre as mesmas, e as boas práticas. Ao final de 2013 foram criados planos de ação (roadmaps) com responsáveis definidos por refinaria, de maneira a garantir o cumprimento da meta.

Nos anos de 2013 e 2014 foram realizadas uma série de apresentações para a alta gerência da empresa, com os resultados alcançados na época. Na figura 4.2 é possível ver na linha do tempo, os principais eventos dos anos de 2013 a 2018. A partir do ano de 2015 os eventos foram menos frequentes.

A política definida em 2013 não foi atualizada até o ano de 2018. A meta do indicador de cada unidade operacional, no entanto, foi revisada anualmente. 


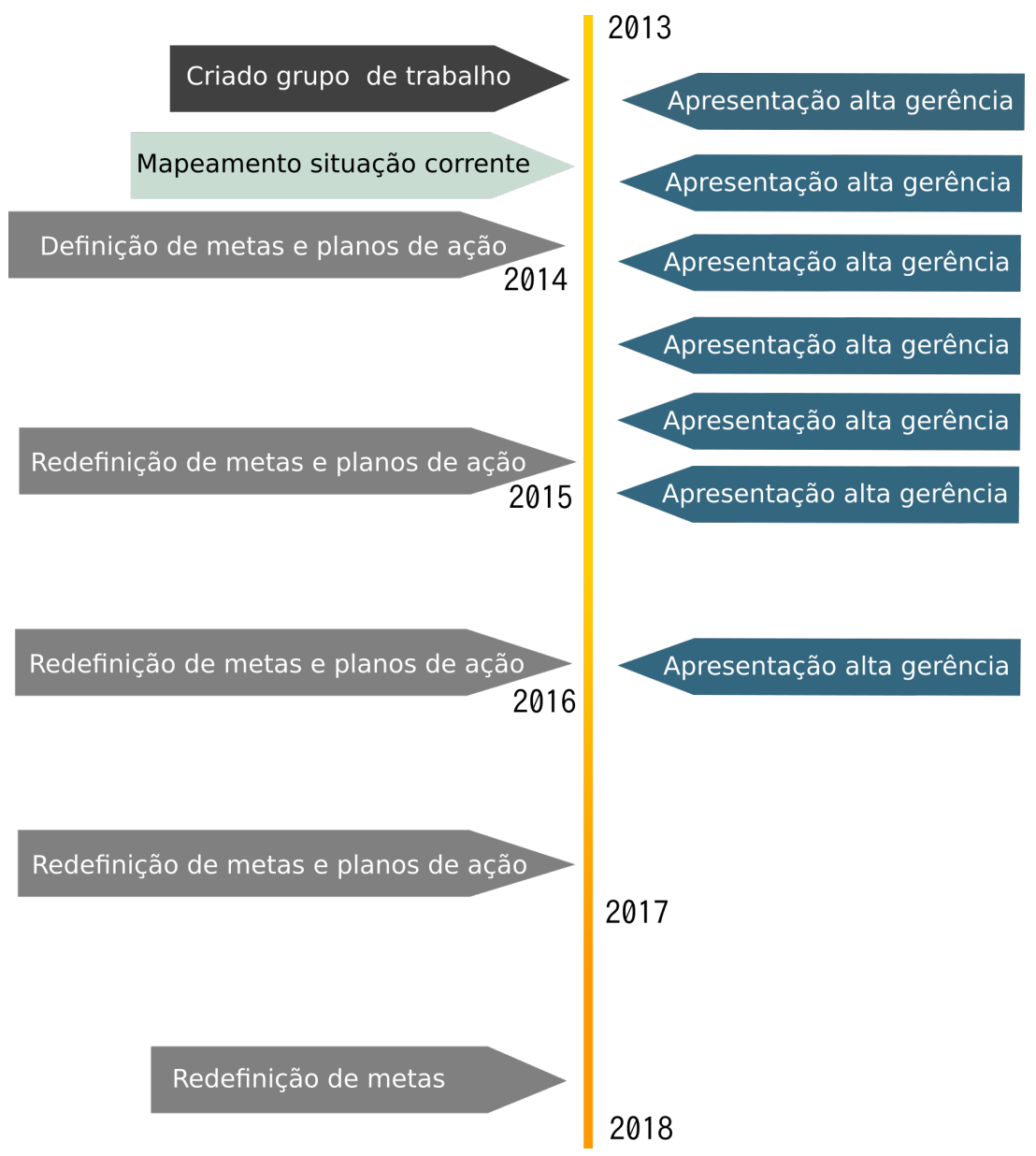

Figura 4.2: Timeline: principais eventos de 2013 a 2018 Fonte: Elaboração própria

\section{2}

\section{Entrevistas}

Para definição do estado atual da gestão dos estoques intermediários, foi desenvolvido um questionário direcionado eletronicamente para responsáveis nas unidades operacionais e na sede pelo indicador de estoques intermediários. Dos 13 questionários enviados, 6 foram respondidos. Os resultados a seguir são uma compilação dessas respostas.

A primeira pergunta diz respeito ao entendimento quanto à finalidade do estoque intermediário. De forma geral, todos os respondentes pontuaram o estoque intermediário necessário para a carga de unidades e o estoque intermediário de produtos semi-acabados. Abaixo um exemplo de resposta recebida, que ilustra esse entendimento. 
produção/qualidade dos produtos finais em caso de alterações nos processos à montante/jusante."

A segunda pergunta referiu-se ao atual processo de definição das metas a serem perseguidas para o estoque intermediário. Os respondentes foram questionados se nessa definição, na opinião dos mesmos, são envolvidas todas as áreas correlatas e, caso negativo, que fossem indicadas quais outras áreas deveriam ser envolvidas. Nesse item não houve consenso entre as respostas. Metade dos respondentes disseram que todas as áreas necessárias são envolvidas enquanto a outra metade disse que não, ficando a definição apenas entre a área operacional de programação de produção juntamente com a área de sede que coordena o assunto.

"Aqui na refinaria vejo pouca interferência da área financeira, ou seja, quanto custa manter este estoque. A definição é feita basicamente por nós, da programação da produção, com alguma influência das áreas da produção, transferência e estocagem, e otimização."

Foi questionado ainda se na atual definição da meta de estoques intermediários os fatores monetários são considerados e, em caso positivo, quais seriam esses fatores. Para essa questão também não houve uniformidade nas opiniões. Foram citados como custos considerados: custos de oportunidade do estoque parado, custo marginal para acúmulo ou "desova", custo de parada de unidade e/ou segurança operacional. Foi citado também por alguns respondentes que custos não são considerados, sendo o histórico dos estoques mais importante.

\footnotetext{
"Definimos nossa meta em função do histórico operacional, folgas em relação a estoques mínimos obrigatórios, confiabilidade (de unidades, dutos, etc.)"
}

O nível de confiabilidade dos processos foi considerado por metade dos respondentes como sendo relevante para a definição dos estoques intermediário. Interessante notar que em uma das respostas, abaixo explicitada, foi apontada a lógica do pulmão no processo, se o processo seguinte falha, é necessário manter disponível espaço para o produto da unidade anterior para que essa não precise ser interrompida ao mesmo tempo.

"Sem dúvida a confiabilidade do processo deve ser considerada no dimensionamento do estoque intermediário, se tenho uma unidade de 
craqueamento que falha muito, tenho que manter o estoque de gasóleo mais baixo, por outro lado, se minha destilação é pouco confiável, seria o contrário."

No entanto, não foi relatado nenhum tipo de acompanhamento de perdas de processamento em função dos níveis de estoque intermediário. Da mesma forma, não foi evidenciado também acompanhamento de perda de vendas por indisponibilidade de produto final provocada pela falta de componentes.

Na última pergunta direcionada às unidades operacionais, houve consenso nas respostas de que a definição da meta leva em conta paradas programadas de unidades de processo.

"Em grandes paradas os níveis de estoques são bastante diferentes dos niveis em períodos normais de operação; por exemplo, ano passado chegamos a aumentar em quase $100 \%$ nosso estoque intermediário durante parada programada de um craqueamento."

\section{3}

\section{Análise dos estoques da empresa}

A partir dos dados coletados no banco de movimentação e estoques da empresa, relativos ao fechamento do ano de 2017, foram construídos os gráficos apresentados nas figuras 4.3, 4.4 e 4.5. O percentual apresentado no eixo dos gráficos é relativo ao valor monetário de cada um dos estoques.

Conforme apresentado na figura 4.3, os diferentes produtos intermediários são primariamente classificados em "processo", "mistura", "parafina", "macro", "consumo", "alifático", "naftênico" e "micro". As classes "processo" e "mistura" correspondem juntas a $89 \%$ de todos os estoques, sendo as demais classes relativas a cortes específicos utilizados na produção de parafinas e lubrificantes, salvo "consumo", que é utilizado para consumo interno. Na classe "processo" encontra-se todos os estoques que são utilizados como carga das unidades de processo, e na classe "mistura", aqueles que são usados como componentes de produtos finais.

Ainda em uma análise agregada, é possível a combinação dos produtos em diferentes famílias, ou classes secundárias. A distribuição em relação à classe secundária é apresentada na figura 4.4. Quatro classes secundárias respondem por cerca de $80 \%$ dos custos de todos os estoques. São elas: gasóleo, diesel intermediário, nafta intermediária e resíduo de refino. As barras em azul 


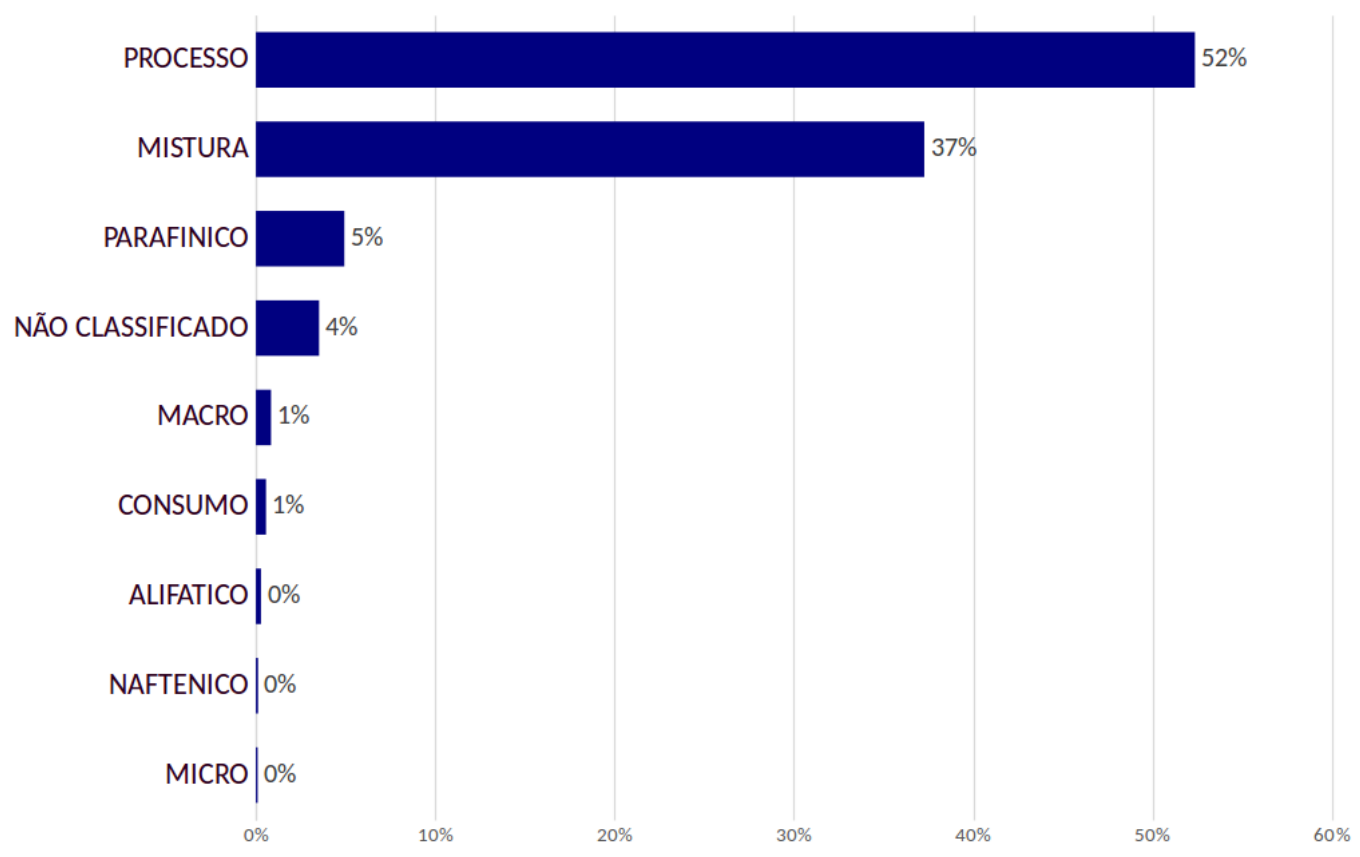

Figura 4.3: Distribuição de produtos por tipo Fonte: Elaboração própria

representam o percentual de participação nos valores monetários de cada um dos estoques, e a curva em vermelho, o percentual acumulado.

Na figura 4.5, é apresentada a distribuição dos valores monetários dos estoques por produto de um total de 105 produtos intermediários diferentes. Desses, 25 produtos são responsáveis por $80 \%$ dos custos totais. Vale ressaltar que todos os 105 produtos são igualmente tratados na gestão dos estoques intermediários atual da empresa, uma vez que a análise e definição de indicadores é realizada de forma agregada. 


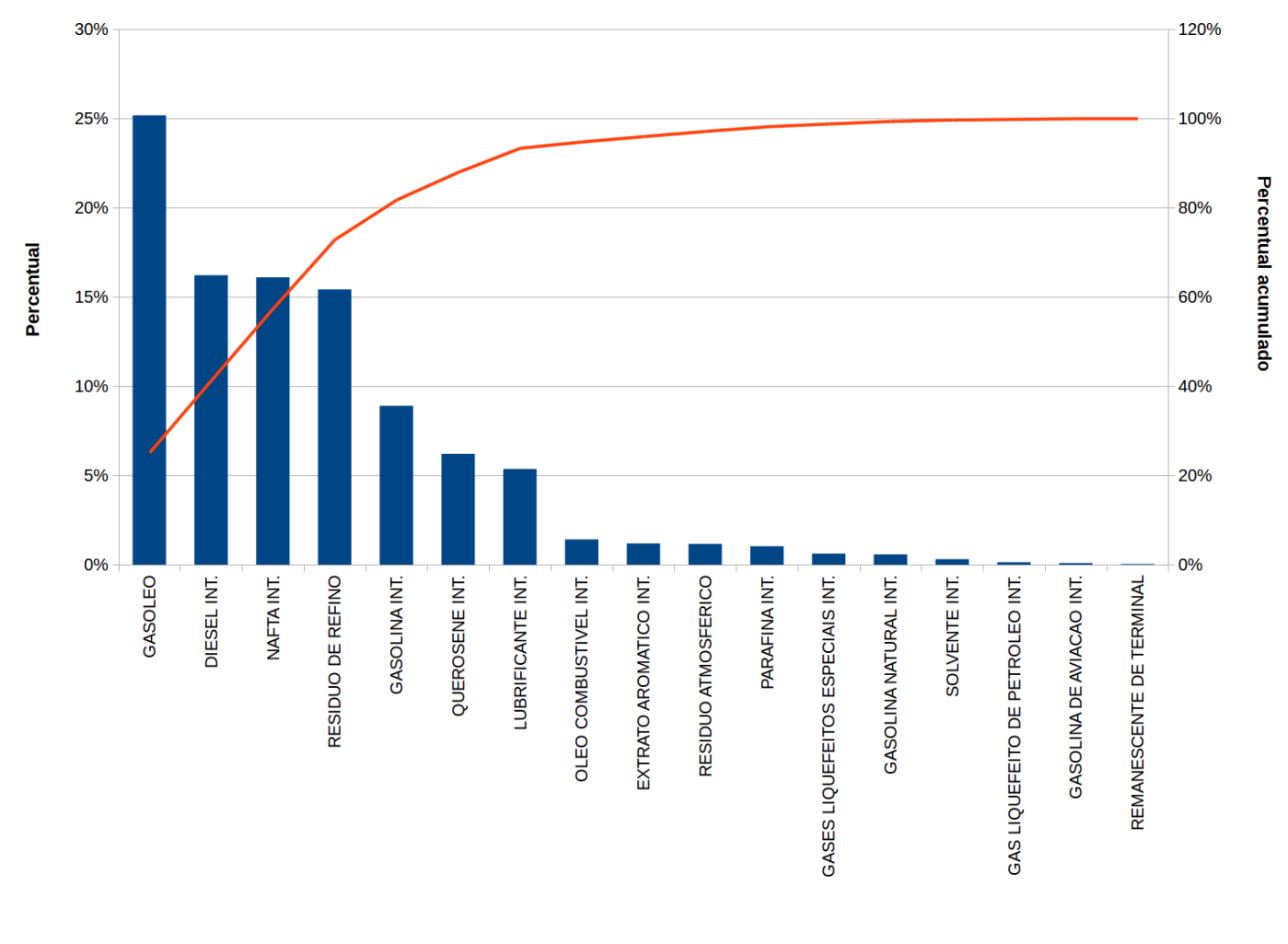

Figura 4.4: Distribuição dos estoques por classe secundária Fonte: Elaboração própria 


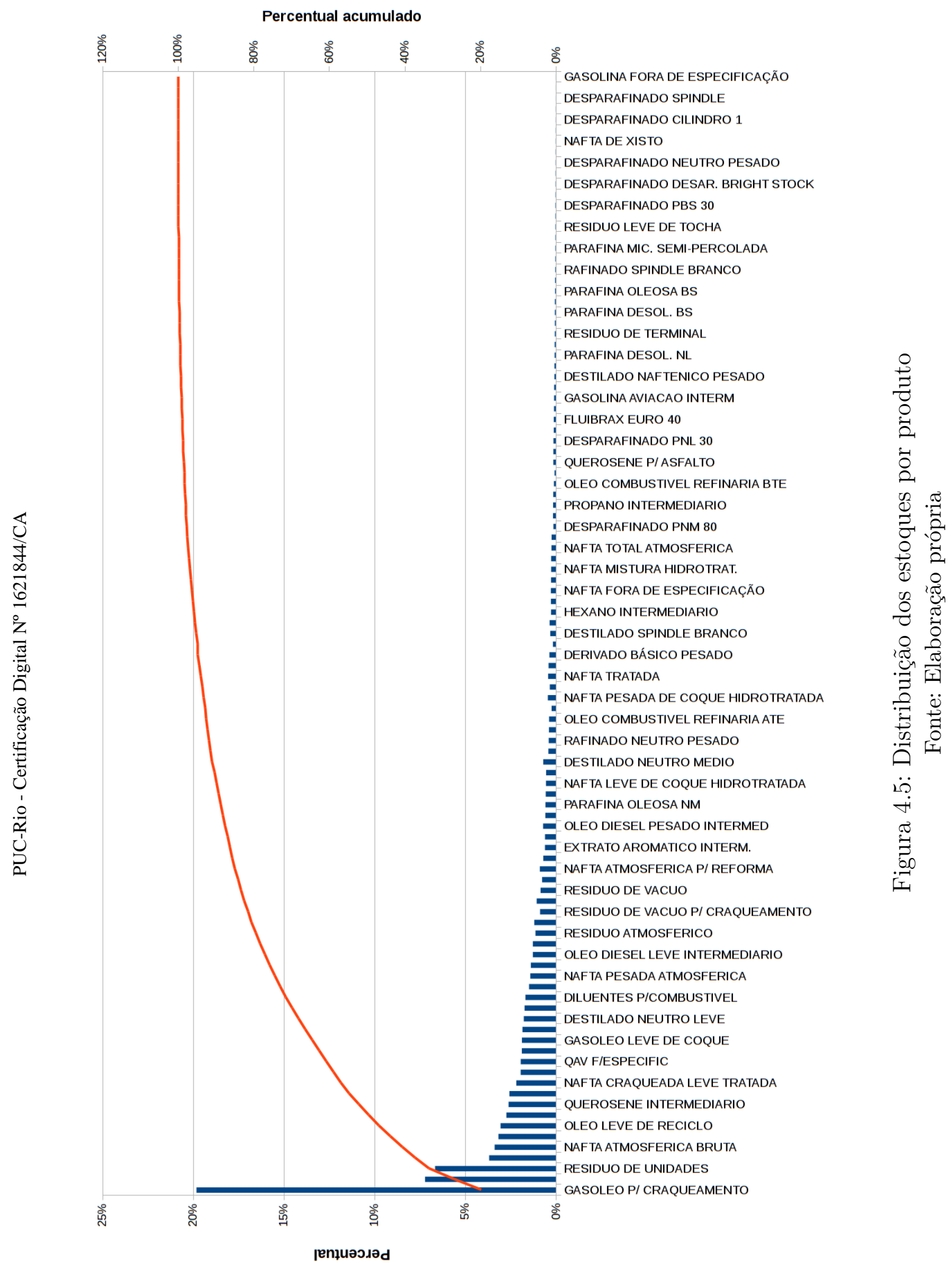




\section{4 \\ Proposição de framework para gestão de produtos intermediários em uma empresa de petróleo}

Com base na revisão bibliográfica sistemática, no referencial teórico e nas evidências analisadas do estudo de caso, um framework de gestão de estoques intermediários é apresentado na figura 4.6 para a empresa. A etapa de definição de diretrizes e estratégias é uma etapa crítica, já que as decisões tomadas nessa fase afetam todo o escopo do trabalho posterior. Por esse motivo, sugere-se que haja o envolvimento multi-disciplinar, com definições claras de responsáveis técnicos e gerenciais. Os papéis e responsabilidades de cada um dos representantes deve ser claramente definido através de uma matriz de responsabilidades. A coordenação desse processo deve ser realizada pela área que possui a gestão, controle e ação direta em relação aos níveis de inventários intermediários da empresa. Sugere-se minimamente a participação das áreas de programação de produção (refinarias e sede), planejamento operacional, processos, transferência e estocagem, comercial e financeiro. Os seguintes itens compõe essa fase:

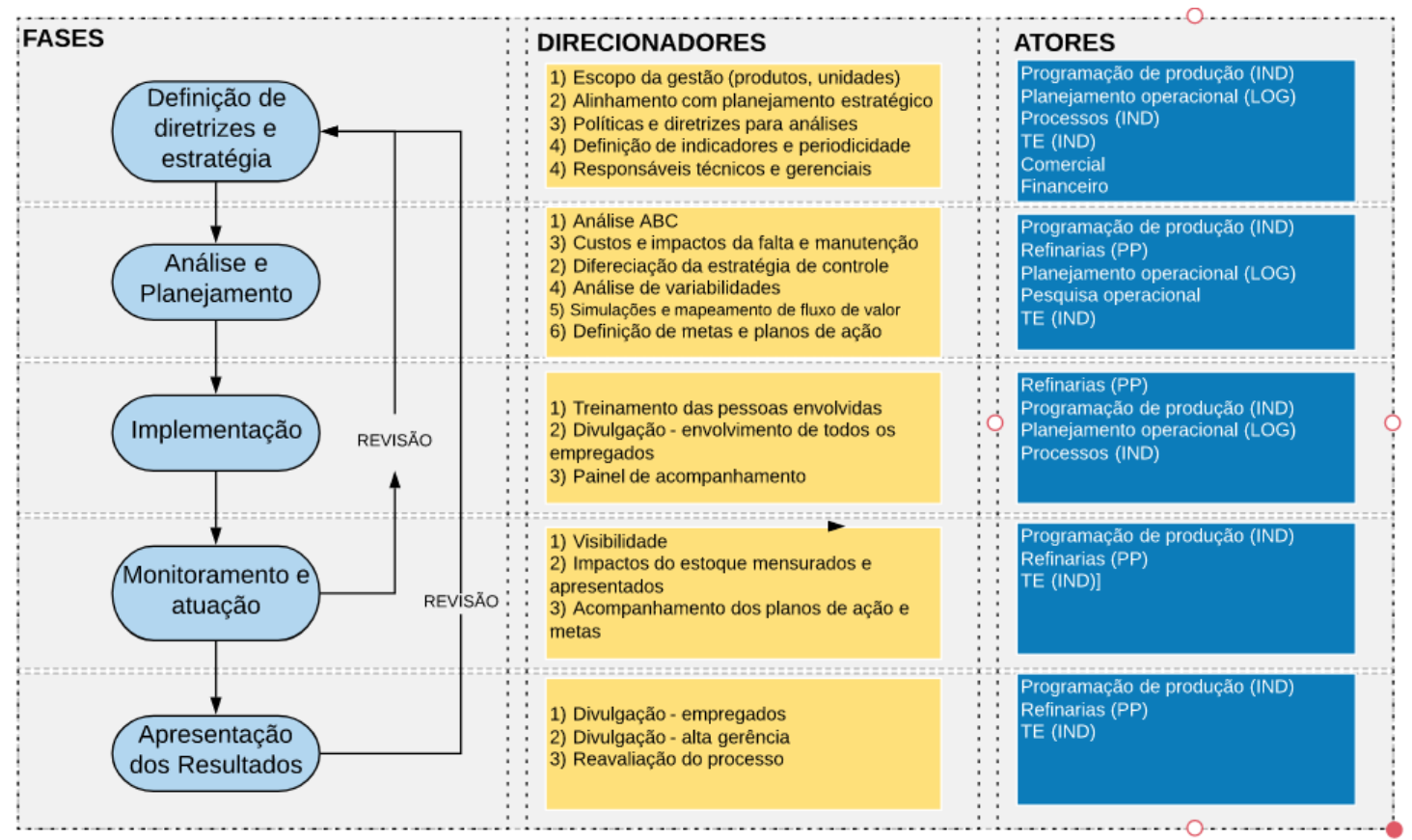

Figura 4.6: Framework proposto para a gestão de estoques intermediários Fonte: Elaboração própria. 
Definição do escopo da gestão Deve ser inicialmente definido a quais tipos de produto a gestão se destina: se a todos os produtos intermediários ou só parte deles. Como exemplo, pode-se avaliar apenas os estoques intermediários que são carga de unidades, ou apenas os produtos semi-acabados. Para essa definição deve ser realizado estudo detalhado sobre o inventário para verificação de nível atual de estoques intermediários em termos monetários, gestão corrente, níveis de serviço, custos associados, entre outros.

Alinhamento com o planejamento estratégico Todas as decisões realizadas devem estar coerentes com o planejamento estratégico. Por exemplo, se a companhia quer garantir estrategicamente que todas as suas unidades operacionais operem em plena carga, o impacto na política de gestão de estoques é diferente do que se o direcionador fosse redução de todos os custos operacionais. Sugere-se que esse ponto seja alinhado em reuniões gerenciais específicas para tratamento do assunto.

Política e diretrizes Para a definição das diretrizes, os seguintes itens devem ser avaliados:

- Nível atual de inventário (agregado) em termos monetários;

- Principais características, tais como configurações de estoque, da companhia e verificação das práticas empregadas nas indústrias que mais se assemelham a ela;

- Levantamento dos impactos decorrentes dos diferentes níveis de estoque;

- Procedimento e critérios para a avaliação ABC;

- Diferenciação e definição das estratégias de controle de estoque por tipo $(\mathrm{ABC})$;

- Definição de indicadores e periodicidade de controle por tipo definido $(\mathrm{ABC})$;

- Definição de conceitos e ferramentas da filosofia lean e da filosofia Six Sigma a serem utilizados;

- Necessidade de comunicação do processo à força e trabalho, para ampliação do envolvimento dos empregados;

- Definição de ferramentas de controle (painéis, por exemplo), para transparência das informações do processo;

- Identificação de casos singulares; e 
- Periodicidade de reanálise das diretrizes.

Após a definição das diretrizes, o resultado deve ser apresentado ao corpo gerencial superior para verificação do alinhamento. Com o procedimento e critérios estabelecidos, deve ser inicialmente realizada a avaliação ABC dos estoques. Essa análise deve ser feita tanto em nível local (pela refinaria), quanto em nível geral (pela sede). Assim, as formas de controle dos diferentes tipos de estoque podem ser diferenciadas. Devem ser avaliadas também quais conceitos e ferramentas da filosofia lean e Six Sigma são adequados para aplicação na empresa.

Para itens críticos, deve ser realizada o mapeamento do fluxo de valor e simulação para verificação de potenciais ganhos econômicos ao longo do processo com a minimização dos estoques. Com o mesmo propósito, devem também ser avaliadas as diferentes variabilidades a que cada tipo de estoque está sujeito. Dessa maneira, as regras para definição de metas de controle não são genéricas, e sim específicas para cada tipo de sistema e estoque. Nessa etapa, o departamento de pesquisa operacional da empresa pode oferecer suporte para modelagens que se façam necessárias. A área de planejamento operacional deve avaliar também os impactos financeiros dos níveis de estoque sugeridos, do ponto de vista global do sistema.

Deve ainda ser realizada nessa fase uma avaliação histórica quanto à utilização dos estoques. Aqueles que aparentemente só existem por razões históricas devem ser zerados. As metas dos estoques devem ser desagregadas, de maneira a dar visibilidade aos tipos mais críticos de produtos. Cada unidade operacional possui sua própria meta, que deve ser negociada com os responsáveis técnicos da sede, de acordo com os direcionadores definidos.

Com a definição das metas, devem ser criados planos de ação para seu cumprimento. Cabe ressaltar que as metas devem considerar sazonalidades e situações previstas no planejamento, como parada de unidades para manutenção programada.

$\mathrm{Na}$ fase de implementação deve ser garantido que todos participantes do processo estejam alinhados com as premissas e objetivos, através da realização de treinamentos. Isso faz com que seja evitada ambiguidade no entendimento, e a força de trabalho se esforce sempre na mesma direção.

Adicionalmente, para que isso aconteça, deve ser realizada também ampla divulgação da política e diretrizes da gestão de estoques intermediários. Deve ser implementado controle transparente e as pessoas que atuam diretamente nesse controle devem estar devidamente treinadas. Sugere-se a implementação 
de um painel de acompanhamento, no qual tanto os níveis e custos de manutenção e falta do estoque são acompanhados, quanto a realização dos planos de trabalho previstos. Importante que o sistema de controle seja unificado para que não existam controles paralelos. Recomenda-se que o sistema esteja integrado também com sistemas de produção, planejamento, manutenção e demais atividades que possam afetar os estoques intermediários.

Os indicadores, metas e planos de ações previstos devem ser acompanhados na fase de monitoramento. A classificação do tipo de estoque indica a frequência com a qual o acompanhamento deve ser realizado. Dessa maneira, itens do tipo A possuem acompanhamento mais amiúde, enquanto itens do tipo $\mathrm{C}$ possuem acompanhamentos menos frequentes.

Caso o resultado alcançado para o indicador esteja fora dos limites estabelecidos, a unidade operacional deve apresentar análise crítica e plano de controle do indicador. Pode ser que uma nova configuração de produção, mercado, logística tenha se estabelecido e que a política para determinado estoque deva ser reavaliada.

Periodicamente, os resultados globais do processo estabelecido para a gestão de estoques devem ser apresentados tanto para os empregados, quanto para o corpo gerencial. Isso traz visibilidade para o trabalho que foi desenvolvido e motivação para os envolvidos.

O processo global deve ser revisado periodicamente, com frequência superior a uma vez por ano, retornando à fase de definição e diretrizes. Isso garante que variáveis como custos dos produtos, variabilidades de produção, incertezas de mercados, por exemplo, sejam constantemente revisadas, sem a consideração estática das premissas.

\section{5}

\section{Comparação do framework proposto e a situação atual}

A tabela 4.2 apresenta todas as recomendações levantadas a partir do framework de gestão de estoques intermediários e a comparação com a situação atual evidenciada. A primeira recomendação listada é a utilização de sistema com alta visibilidade do processo de maneira a garantir que todos os atores do processo tenham acesso às informações de forma ágil e padronizada. A empresa faz a gestão do indicador em sistema de alta visibilidade, no entanto, outras informações relevantes não encontram-se na mesma visão, como custos de estoques e níveis de serviço, por exemplo. Recomenda-se assim a implementação de um sistema integrado com alta visibilidade. 


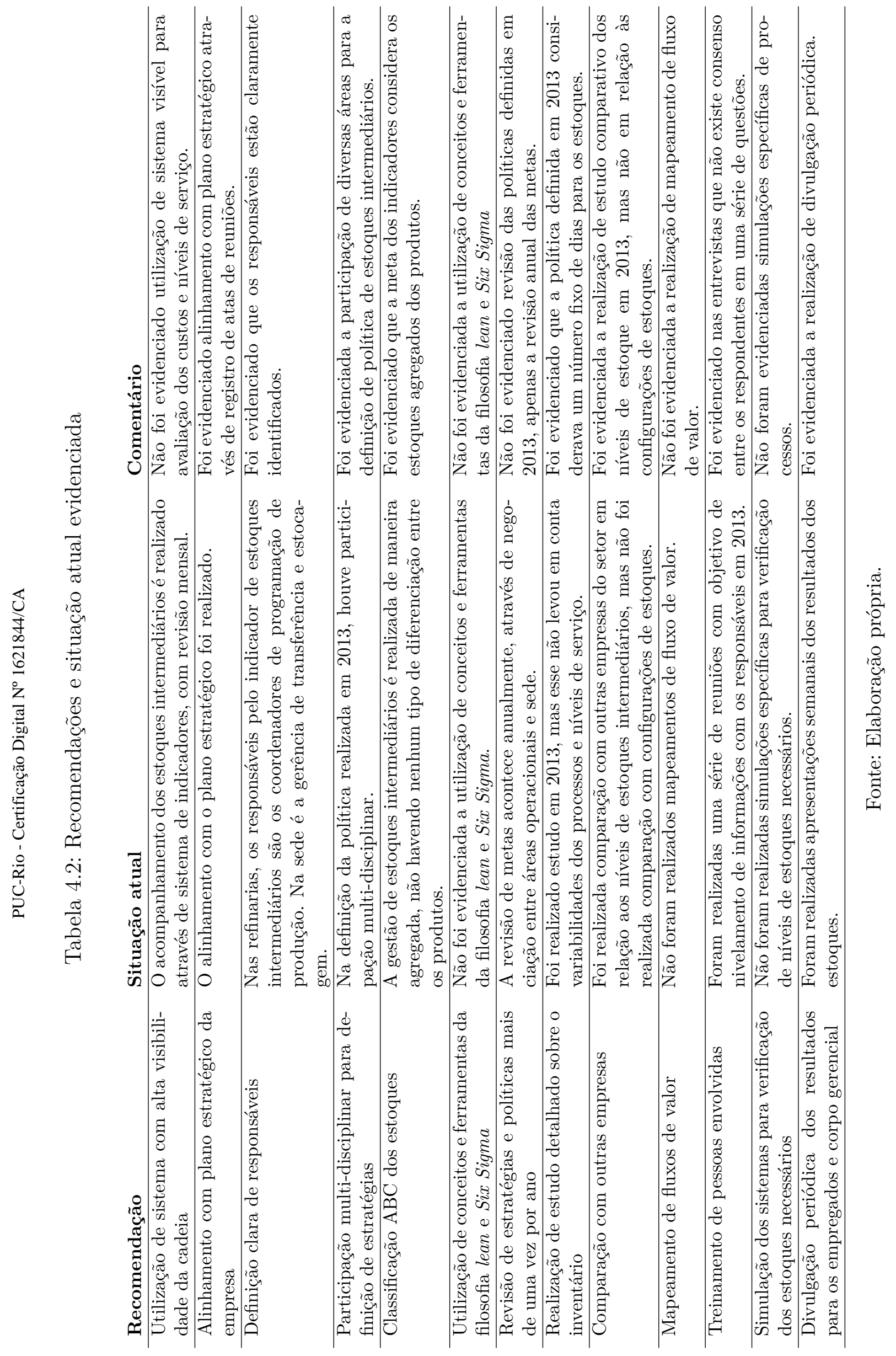


O alinhamento com plano estratégico também é uma prática que deve ser seguida. Na empresa, houve alinhamento no período de definição da política de estoques intermediários.

Não foi evidenciada a realização de classificação ABC dos estoques da empresa, tampouco diferenciação de controle por tipo de estoque ABC. A definição das metas é realizada de maneira agregada, sem a consideração de custos e impactos relativos ao excesso ou à falta de estoques específicos. Foi evidenciada que a definição inicial de níveis de estoques levou em consideração comparação realizada com os níveis de estoque intermediários de outras empresas do mesmo ramo, mas não houve estudo comparativo relacionado às configurações dos estoques de outras companhias.

A revisão de estratégias e políticas com periodicidade superior a uma vez por ano não foi evidenciada. Ao final de cada ano, as metas são revistas, mas a estratégia em si continua sendo a mesma que foi definida em 2013, sem revisão posterior.

A empresa não realiza mapeamento de fluxos de valor ou simulação específica para avaliação dos estoques intermediários necessários. Os estudos iniciais realizados consideraram os níveis históricos de estoque, mas não foram considerados as variações e os graus de confiabilidade específicos de cada sistema, em um estudo detalhado.

Ao longo do programa de gestão de estoques intermediários da empresa foram realizadas apresentações periódicas para os empregados e corpo gerencial. No entanto, não foram evidenciadas realizações de treinamento oficiais. Nas entrevistas, foi identificado ausência de consenso em muitas questões, o que indica necessidade de treinamento e realinhamento da força de trabalho.

A tabela 4.3 apresenta as recomendações e a referência de estudo utilizada para sua elaboração. Vale a pena ressaltar que as referências foram consideradas na avaliação das facilidades e impactos para as recomendações consideradas como não atendidas, apresentadas na sequência. 
Tabela 4.3: Recomendações e referências de estudos

\begin{tabular}{|c|c|}
\hline Recomendação & Referência \\
\hline $\begin{array}{l}\text { Classificação ABC dos estoques } \\
\text { e diferenciação dos tipos de con- } \\
\text { trole }\end{array}$ & (Silver et al., 2016), (Aberdeen, 2006) \\
\hline $\begin{array}{l}\text { Revisão de estratégias e políticas } \\
\text { mais de uma vez por ano }\end{array}$ & (Aberdeen, 2006) \\
\hline $\begin{array}{l}\text { Utilização de sistema com alta vi- } \\
\text { sibilidade da cadeia }\end{array}$ & (Aberdeen, 2006), (Hwang, 2006) \\
\hline $\begin{array}{l}\text { Treinamento de pessoas envolvi- } \\
\text { das }\end{array}$ & (Silver et al., 2016) \\
\hline Mapeamento de fluxo de valor & $\begin{array}{l}\text { (Abdulmalek \& Rajgopal, 2007), e } \\
\text { (Jeyaraj et al., 2013) }\end{array}$ \\
\hline $\begin{array}{l}\text { Realização de estudo detalhado } \\
\text { do inventário }\end{array}$ & (Silver et al., 2016) \\
\hline $\begin{array}{l}\text { Modelagem e simulação dos siste- } \\
\text { mas para determinação do esto- } \\
\text { que necessário }\end{array}$ & $\begin{array}{l}\text { (Orcun et al., 2009), (Aksoy \& Gupta, } \\
\text { 2011), (Manoj et al., 2012), (Schwartz } \\
\text { \& Rivera, 2010), (Wang et al., 2007) }\end{array}$ \\
\hline $\begin{array}{l}\text { Disseminação de conceitos da fi- } \\
\text { losofia lean }\end{array}$ & 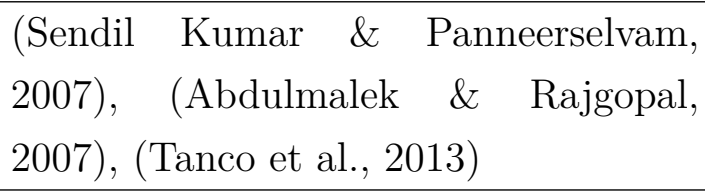 \\
\hline $\begin{array}{l}\text { Comparação com outras empre- } \\
\text { sas (configuração dos estoques) }\end{array}$ & (Demeter \& Golini, 2014) \\
\hline $\begin{array}{l}\text { Alinhamento com plano estraté- } \\
\text { gico da empresa }\end{array}$ & (Silver et al., 2016), (Aberdeen, 2006) \\
\hline Definição clara de responsáveis & (Silver et al., 2016) \\
\hline $\begin{array}{l}\text { Participação multi-disciplinar } \\
\text { para definição de estratégias }\end{array}$ & (Silver et al., 2016), (Aberdeen, 2006) \\
\hline $\begin{array}{l}\text { Divulgação periódica dos resulta- } \\
\text { dos para os empregados e corpo } \\
\text { gerencial }\end{array}$ & (Silver et al., 2016), (Aberdeen, 2006) \\
\hline
\end{tabular}

Para a avaliação da facilidade de implementação de cada recomendação, foi realizada uma estimativa de necessidade de homem-hora para execução quanto mais baixo, maior a facilidade de implementação. Os valores propostos foram validados por avaliador interno não tendencioso. No caso da verificação dos impactos de cada recomendação, foram consideradas duas dimensões: a 


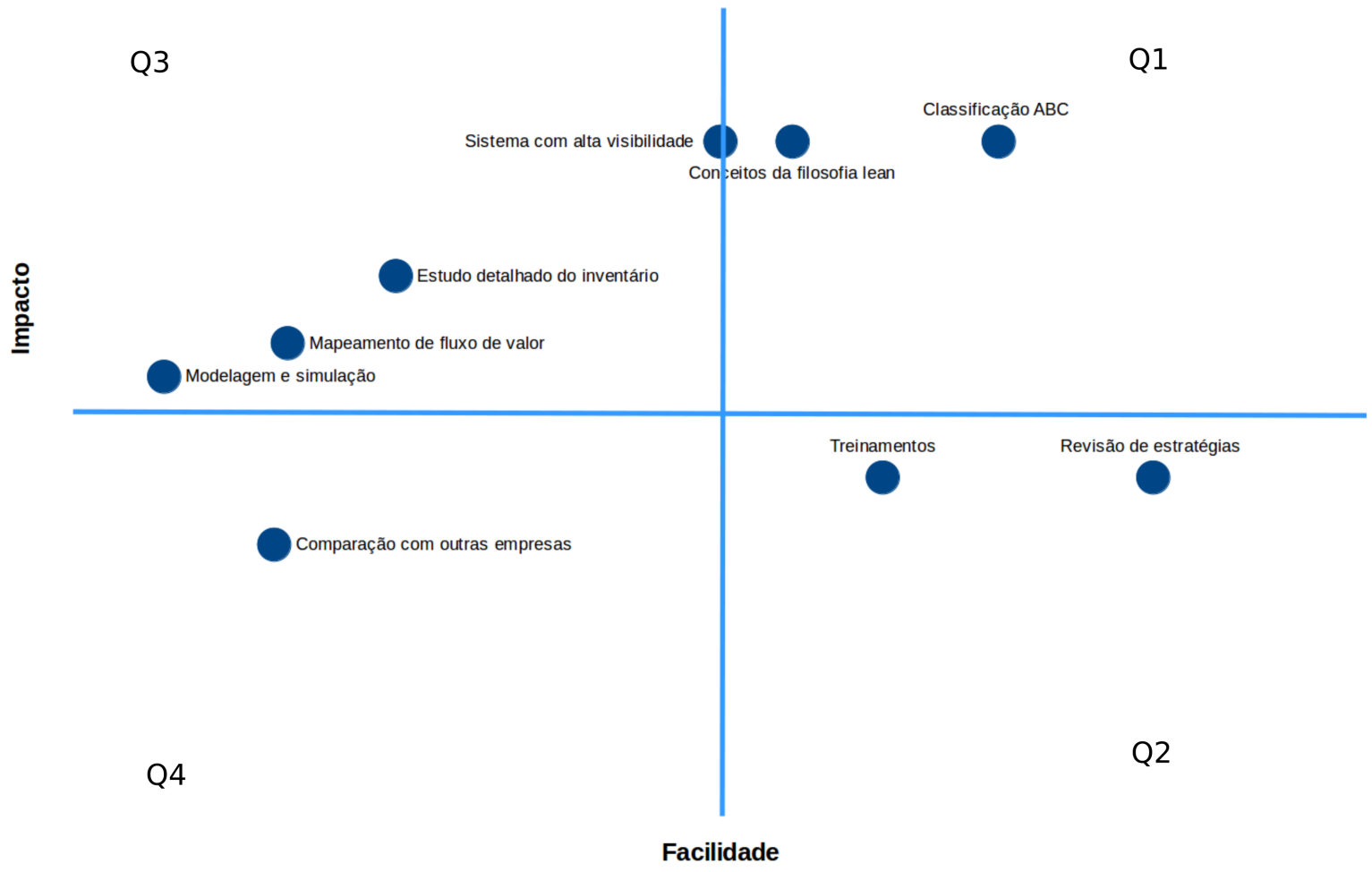

Figura 4.7: Facilidade versus impacto de implementação das recomendações Fonte: Elaboração própria.

redução potencial nos estoques intermediários e o aumento do foco e agilidade da gestão, em escalas de 0 a 100\%. O produto dessas parcelas corresponde ao valor calculado para o impacto. Da mesma forma que a facilidade, o impacto de cada uma das recomendações foi validado com o avaliador interno.

Com as avaliações de facilidade e impacto de implementação, foi construída a figura 4.7 que apresenta um esquema gráfico nos quais as recomendações são separadas em quatro classes. O quadrante Q1 representa alto impacto e alta facilidade de implementação, o quadrante Q2 moderado impacto e alta facilidade, o quadrante Q3 moderada facilidade e alto impacto e o quadrante Q4, moderada facilidade e moderado impacto. Essa figura tem como objetivo direcionar priorização para implantação das propostas. Vale ressaltar que todas elas são consideradas relevantes para a gestão eficaz do gerenciamento dos estoques intermediários na empresa.

Assim, as recomendações Classificação $A B C$ e Utilização de conceitos e ferramentas da filosofia lean foram avaliadas como de alta facilidade e alto impacto, sendo recomendada a implantação prioritária das mesmas na empresa. Na sequência, foram considerada como de alto impacto e moderada 
facilidade de implementação as recomendações Utilização de sistemas com alta visibilidade da cadeia, seguido de Estudo detalhado do inventário, Mapeamento dos fluxos de valor, e Modelagem e simulação dos sistemas.

Como recomendações de moderado impacto e alta facilidade, foram consideradas a Revisão das estratégias de gestão com frequência maior que uma vez por ano e a Realização de treinamentos da força de trabalho. Finalmente, como de moderado impacto e moderada facilidade, foi considerada a recomendação de Estudo de comparação das configurações dos estoques com outras empresas.

A seguir é proposto um roadmap para a empresa seguir para a implementação das recomendações, em ordem de priorização. Vale ressaltar que a ordem elencada foi validada por consultor interno.

- R1 Classificação ABC;

- R2 Utilização de conceitos e ferramentas da filosofia lean;

- R3 Utilização de sistemas com alta visibilidade da cadeia;

- R4 Revisão das estratégias de gestão com frequência maior que uma vez por ano;

- R5 Realização de treinamentos da força de trabalho;

- R6 Estudo detalhado do inventário;

- R7 Mapeamento dos fluxos de valor;

- R8 Modelagem e simulação dos sistemas;

- R9 Estudo de comparação das configurações dos estoques com outras empresas.

Com a implantação das recomendações listadas, a empresa terá ganho de foco e agilidade na sua gestão de estoques intermediários, além de redução nos estoques. Sugere-se como trabalho futuro a realização de estudo quantitativo para dimensionamento exato do ganho. 


\section{Conclusões}

Elevado custo com estoques é ainda um problema enfrentado por muitas empresas brasileiras. Reduzir esse custo mostra-se como uma oportunidade, mas essa redução deve ser acompanhada de uma análise criteriosa, de maneira a não trazer consequências indesejáveis como parada de unidades ou perda de mercado.

O foco dessa dissertação foi a análise da gestão dos estoques intermediários de uma empresa de petróleo. Inicialmente, foi realizada pesquisa bibliográfica para consolidação do referencial teórico. Nessa fase, observou-se a necessidade de aprofundamento e uma revisão de literatura sistemática foi efetivada para responder à pergunta "Quais as práticas de gestão de inventários intermediários são empregadas na indústria de processo?". De acordo com os resultados apresentados no capítulo 3, as seguintes práticas são apontadas como atualmente relevantes nos estudos:

1. Avaliação e definição das principais características da indústria de processo e a verificação das práticas empregadas nas indústrias que mais se assemelham a ela;

2. Avaliação e definição das configurações de estoque da indústria de processo e a verificação das práticas empregadas nas indústrias que possuem configurações similares;

3. Utilização de princípios e ferramentas da filosofia lean na gestão dos estoques intermediários, com especial atenção ao mapeamento de fluxo de valor;

4. Utilização de sistemas de controle com informações centralizadas relativas a estoques, produção e manutenção com transparência na apresentação das informações;

5. Realização de simulações com objetivo de verificação de ganho potencial de implementação de estratégias de controle de estoques intermediários. 
Para a análise do estudo de caso, foi elaborado um protocolo de pesquisa. Através de análise de diversos tipos de evidência (registro, entrevista, documentos, observação participativa), o processo de gestão de estoques intermediários da empresa foi mapeado.

Com base na revisão realizada, um framework de gestão de estoques intermediários foi proposto e esse foi comparado com a gestão atual da empresa. Como resultado foram elencadas recomendações, para as quais foram analisadas a facilidade e o impacto da implementação. A seguinte ordem de prioridade foi estabelecida, considerando-se a facilidade de implementação e o impacto:

- R1 Classificação ABC;

- R2 Utilização de conceitos e ferramentas da filosofia lean;

- R3 Utilização de sistemas com alta visibilidade da cadeia;

- R4 Revisão das estratégias de gestão com frequência maior que uma vez por ano;

- R5 Realização de treinamentos da força de trabalho;

- R6 Estudo detalhado do inventário;

- R7 Mapeamento dos fluxos de valor;

- R8 Modelagem e simulação dos sistemas;

- R9 Estudo de comparação das configurações dos estoques com outras empresas.

O presente trabalho contribui para a empresa através da proposição de um roadmap para implementação de recomendações com potencial de redução de estoques intermediários e aumento do foco e agilidade da gestão. Sugere-se a realização de um estudo futuro quantitativo para levantamento dos ganhos quantitativos para a empresa, do tipo modelagem matemática e simulação. Sugere-se ainda a realização de um estudo de caso múltiplo para comparação com outras empresas. 


\section{6 \\ Apêndice}

O protocolo apresentado foi desenvolvido com base nas referências de (Yin, 2009), (Runeson \& Höst, 2008) e (Brereton et al., 2008).

\section{1}

\section{Introdução do estudo de caso}

As seguintes perguntas de pesquisa nortearam o estudo: "Quais as práticas de gestão de inventários intermediários são empregadas no estudo de caso?" e "Como os conceitos, princípios e técnicas de gestão de inventário podem ser aplicados de maneira a melhorar a gestão de inventários intermediários na empresa?". A pergunta "Quais os ganhos são esperados se a empresa utilizar o framework teórico proposto?" foi definida como uma sub-questão.

Para identificação de pesquisa anterior realizada no mesmo campo de estudo, inicialmente foi realizada busca bibliográfica para construção do referencial teórico, abordando conceitos gerais sobre a gestão de estoque. $\mathrm{Na}$ sequência foi realizada revisão bibliográfica sistematizada para verificação das principais práticas atualmente empregadas na gestão de estoques intermediários.

O projeto em questão tratou-se de um caso singular, já que apenas uma empresa de petróleo foi foco da pesquisa e nessa companhia foi avaliado um único processo de gestão de estoques. O objeto de estudo foi o processo de gestão de estoques intermediários, que corresponde à unidade de análise. A unidade de análise embutida foi a estrutura organizacional na qual o processo transcorre.

\section{2}

\section{Procedimento de coleta de dados}

Os seguintes tipos de evidência foram coletados: documentos, registros, entrevistas e observação participante. A observação participante foi realizada através da participação em reuniões específicas sobre o assunto na empresa. 
No levantamento documental, foram analisados documentos disponíveis em pasta eletrônica do setor, como apresentações e relatórios. Para o levantamento de registros, foram analisadas atas de reunião registradas e documentos internos e externos oficiais, com data de emissão registrada. Para a realização das entrevistas, foram definidas cinco perguntas que foram feitas para os pontos focais de gestão de estoques nas unidades operacionais e sede da empresa. São elas:

- Qual a finalidade do estoque intermediário na sua opinião?

- A definição da meta do estoque intermediário ocorre com a participação de todas as áreas da empresa que deveriam ser envolvidas? Se não, qual a área que você acha que deveria participar nessa definição?

- A definição da meta leva em conta fatores monetários? Se sim, quais?

- A definição da meta leva em conta o nível de confiabilidade dos processos?

- A definição da meta leva em conta paradas programadas de unidades?

\section{3}

\section{Análise}

A partir das evidências do tipo registro, foi feita uma linha do tempo, para entendimento e interpretação do processo ao longo do período estudado. A análise documental subsidiou a verificação dos conceitos, ideias, diretrizes que foram construídos na empresa. As entrevistas, assim como a observação participante, foram utilizadas para avaliação do entendimento e engajamento da força de trabalho no processo.

Foi definido que se houvesse grande divergência entre os dados coletados, deveria ser reavaliada a necessidade de extensão do período analisado para o processo e inclusão de novos entrevistados, com papel diferente na gestão. Isso, no entanto, não ocorreu.

\section{4}

\section{Validação}

De maneira a garantir a validade e confiabilidade do estudo foram verificadas múltiplas fontes de evidências, com estabelecimento da cadeia de evidências. Os dados levantados nos documentos e registros foram triangulados com as respostas recebidas das entrevistas. Adicionalmente, o rascunho do relatório foi apresentado para revisão por um verificador não tendencioso que trabalha na unidade de análise investigada e conhece bem o processo estudado. 
Os estudos externos encontrados ao longo do trabalho foram via de regra concordantes com os resultados obtidos.

\section{5}

\section{Apresentação do relatório}

O relatório desse estudo de caso será apresentado para a empresa analisada e para a universidade onde está sendo realizado o curso de mestrado. No primeiro caso, espera-se a participação do corpo gerencial e do corpo técnico da empresa que participam da gestão estudada, enquanto que no segundo caso, espera-se a participação de professores e alunos que pesquisam assuntos correlatos. 


\section{Referências bibliográficas}

Abdulmalek, F. A., \& Rajgopal, J. (2007). Analyzing the benefits of lean manufacturing and value stream mapping via simulation: A process sector case study. International Journal of Production Economics, 107(1), 223 - 236. Retrieved from http://www.sciencedirect.com/science/ article/pii/S0925527306002258 (Special Section on Building CoreCompetence through Operational Excellence) doi: https://doi.org/10.1016/ j.ijpe.2006.09.009

Aberdeen, G. (2006, September). The technology strategies for inventory management. Retrieved from http://www.ceoconsulting.ru/upload/ files/InvMgtreport_Aberdeen.pdf?id=26

Aksoy, H. K., \& Gupta, S. M. (2011, Jun 01). Optimal management of remanufacturing systems with server vacations. The International Journal of Advanced Manufacturing Technology, 54(9), 1199-1218. Retrieved from https://doi.org/10.1007/s00170-010-3001-z doi: 10.1007/ s00170-010-3001-z

API. (2012). Refinery process. website. Retrieved from http://www.api.org/ oil-and-natural-gas/wells-to-consumer/fuels-and-refining/ refineries/how-refinery-works/refinery-processes

Bowersox, D., Closs, D., Cooper, M., \& Bowersox, J. (2014). Gestão logística da cadeia de suprimentos (Quarta edição ed.).

Brereton, P., Kitchenham, B., Budgen, D., \& Li, Z. (2008, 01). Using a protocol template for case study planning. , 2008.

Conway, R., Maxwell, W., O. McClain, J., \& Thomas, L. $(1988,04)$. The role of work-in-process inventory in serial production lines. , 36, 229-241.

Crandall, R. E., \& Crandall, W. R. (2003). Managing excess inventories: A life-cycle approach. The Academy of Management Executive, 99-113.

Dallery, Y., \& Gershwin, S. B. (1992, Mar 01). Manufacturing flow line systems: a review of models and analytical results. Queueing Systems, 12(1), 3-94. Retrieved from https://doi.org/10.1007/BF01158636 doi: 10.1007/BF01158636

Demeter, K., \& Golini, R. (2014). Inventory configurations and drivers: An inter- 
national study of assembling industries. International Journal of Production Economics, 157, 62 - 73. Retrieved from http://www.sciencedirect .com/science/article/pii/S0925527313004593 (The International Society for Inventory Research, 2012) doi: https://doi.org/10.1016/j.ijpe .2013.10.018

Dennis, D. R., \& Meredith, J. R. (2000). An analysis of process industry production and inventory management systems. Journal of Operations Management, 18(6), 683 - 699. Retrieved from http://www.sciencedirect.com/ science/article/pii/S0272696300000395 (Configuration in Operations management: Taxonomies and Typologies) doi: https://doi.org/ 10.1016/S0272-6963(00)00039-5

Dubois, A., \& Gadde, L.-E. (2002, 07). Systematic combining: An abductive approach to case research. , 55, 553-560.

Fahim, M., Al-Sahhaf, T., \& Elkilani, A. (2009). Fundamentals of petroleum refining. Elsevier Science. Retrieved from https://books.google.com .br/books?id=UcFsv1mMFHIC

Gillham, B. (2000). Case study research methods. Bloomsbury Academic. Retrieved from https://books.google.com.br/books?id=BOUdlaxwiXOC

Hayes, R., \& Wheelwright, S. (1979). Link manufacturing process and product life cycles. Harvard Business Review.

Hwang, Y.-D. (2006, Nov 01). The practices of integrating manufacturing execution systems and six sigma methodology. The International Journal of Advanced Manufacturing Technology, 31(1), 145-154. Retrieved from https://doi.org/10.1007/s00170-005-0164-0 doi: 10.1007/s00170 -005-0164-0

Jaffe, A. M., \& Soligo, R. (2002). The role of inventories in oil market stability. The Quarterly Review of Economics and Finance, 42(2), 401 - 415. Retrieved from http://www.sciencedirect.com/science/article/pii/ S1062976902001369 doi: https://doi.org/10.1016/S1062-9769(02)00136 $-9$

Jeyaraj, K. L., Muralidharan, C., Mahalingam, R., \& Deshmukh, S. G. (2013, Jan 01). Applying value stream mapping technique for production improvement in a manufacturing company: A case study. Journal of The Institution of Engineers (India): Series C, 94(1), 43-52. Retrieved from https://doi . org/10.1007/s40032-012-0053-x doi: 10.1007/s40032-012-0053-x

Korytkowski, P., Wisniewski, T., \& Rymaszewski, S. (2013). Multivariate simulation analysis of production leveling (heijunka) - a case 
study. IFAC Proceedings Volumes, 46(9), 1554 - 1559. Retrieved from http://www.sciencedirect.com/science/article/pii/ S1474667016345141 (7th IFAC Conference on Manufacturing Modelling, Management, and Control) doi: https://doi.org/10.3182/20130619-3-RU $-3018.00285$

Kovács, G., \& Spens, K. M. (2005). Abductive reasoning in logistics research. International Journal of Physical Distribution \& Logistics Management, 35(2), 132-144. Retrieved from https://doi.org/10.1108/ 09600030510590318 doi: 10.1108/09600030510590318

Leffler, W. (2008). Petroleum refining in nontechnical language. PennWell. Retrieved from https://books.google.com.br/books?id=zIM6UjoFTHAC

Lima, C., Relvas, S., \& Barbosa-Póvoa, A. P. F. (2016). Downstream oil supply chain management: A critical review and future directions. Computers \& Chemical Engineering, 92, 78 - 92. Retrieved from http://www.sciencedirect.com/science/article/pii/ S0098135416301508 doi: https://doi.org/10.1016/j.compchemeng.2016 .05 .002

Lima, M. (2014, November). Custos log/sticos no brasil. Retrieved from http://www.ilos.com.br/web/custos-logisticos-no-brasil/

Manoj, U., Sriskandarajah, C., \& Wagneur, E. (2012). Coordination in a two-stage production system: Complexity, conflict and cooperation. Computers \& Operations Research, 39(6), 1245 - 1256. Retrieved from http://www.sciencedirect.com/science/article/pii/ S0305054810000729 (Special Issue on Scheduling in Manufacturing Systems) doi: https://doi.org/10.1016/j.cor.2010.03.018

Oliveira, C., Bandeira, R., Goes, G., Gonçalves, D., \& D'Agosto, M. (2017). Sustainable vehicles-based alternatives in last mile distribution of urban freight transport: A systematic literature review. Sustainability, 9(8).

Oliveira, M. M. F. (2014). Otimização da cadeia de suprimentos de petróleo sob incerteza e avaliação de risco (Unpublished master's thesis). Universidade Federal do Rio de Janeiro.

Orcun, S., Uzsoy, R., \& Kempf, K. G. (2009). An integrated production planning model with load-dependent lead-times and safety stocks. Computers \& Chemical Engineering, 33(12), 2159 - 2163. Retrieved from http://www.sciencedirect.com/science/article/pii/ S0098135409001975 (FOCAPO 2008 - Selected Papers from the Fifth International Conference on Foundations of Computer-Aided Process Ope- 
rations) doi: https://doi.org/10.1016/j.compchemeng.2009.07.010

Proth, J.-M. (2007). Scheduling: New trends in industrial environment. Annual Reviews in Control, 31(1), 157 - 166. Retrieved from http://www.sciencedirect.com/science/article/pii/ S1367578807000156 doi: https://doi.org/10.1016/j.arcontrol.2007.03 .005

Runeson, P., \& Höst, M. (2008, Dec 19). Guidelines for conducting and reporting case study research in software engineering. Empirical Software Engineering, 14(2), 131. Retrieved from https://doi.org/10.1007/ s10664-008-9102-8 doi: 10.1007/s10664-008-9102-8

Schwartz, J. D., \& Rivera, D. E. (2010). A process control approach to tactical inventory management in production-inventory systems. International Journal of Production Economics, 125(1), 111 - $124 . \quad$ Retrieved from http://www.sciencedirect.com/science/article/pii/ S0925527310000216 doi: https://doi.org/10.1016/j.ijpe.2010.01.011

Sendil Kumar, C., \& Panneerselvam, R. (2007, Mar 01). Literature review of jit-kanban system. The International Journal of Advanced Manufacturing Technology, 32(3), 393-408. Retrieved from https://doi.org/10.1007/ s00170-005-0340-2 doi: 10.1007/s00170-005-0340-2

Silver, E., Pyke, D., \& Thomas, D. (2016). Inventory and production management in supply chains, fourth edition. Taylor \& Francis. Retrieved from https:// books.google.com.br/books?id=aJG_DQAAQBAJ

Tanco, M., Santos, J., Rodriguez, J. L., \& Reich, J. (2013, Sep 01). Applying lean techniques to nougat fabrication: a seasonal case study. The International Journal of Advanced Manufacturing Technology, 68(5), 1639-1654. Retrieved from https://doi.org/10.1007/s00170-013-4960-7 doi: $10.1007 / \mathrm{s} 00170-013-4960-7$

Thome, A. M. T. (2018). Políticas de controle de estoque. (Nota técnica. Departamento de Engenharia Industrial. PUC - RIO.)

Thomé, A. M. T., Scavarda, L. F., \& Scavarda, A. J. (2016). Conducting systematic literature review in operations management.

Waller, M., \& Esper, T. (2014). The definitive guide to inventory management: Principles and strategies for the efficient flow of inventory across the supply chain. Pearson Education, Incorporated. Retrieved from https://books .google.com.br/books?id=cq8_AwAAQBAJ

Wang, W., Rivera, D. E., \& Kempf, K. G. (2007). Model predictive control strategies for supply chain management in semiconductor manufactu- 
ring. International Journal of Production Economics, 107(1), 56 - 77. Retrieved from http://www.sciencedirect.com/science/article/pii/ S0925527306002404 (Special Section on Building Core-Competence through Operational Excellence) doi: https://doi.org/10.1016/j.ijpe.2006.05 .013

Wikner, J., Naim, M. M., Spiegler, V. L., \& Lin, J. (2017). lobpcs based models and decoupling thinking. International Journal of Production Economics, 194, 153 - 166. Retrieved from http://www.sciencedirect.com/ science/article/pii/S0925527317301536 (Special Issue: Innovations in Production Economics) doi: https://doi.org/10.1016/j.ijpe.2017.05.009

Yin, R. (2009). Case study research: Design and methods. SAGE Publications. Retrieved from https://books.google.com.br/books?id=FzawIAdilHkC 